\title{
The Multi-Omics Architecture of Juvenile Idiopathic Arthritis
}

\author{
Xiaoyuan Hou ${ }^{1}$, Huiqi Qu ${ }^{2}{ }^{1}$, Sipeng Zhang ${ }^{1}$, Xiaohui Qi ${ }^{1}{ }^{(}$, , Hakon Hakonarson ${ }^{2,3,4}$, \\ Qianghua $\mathrm{Xia}^{1, *}$ and Jin $\mathrm{Li}^{1,5,6, *(D)}$ \\ 1 Department of Cell Biology, the Province and Ministry Co-sponsored Collaborative Innovation Center for \\ Medical Epigenetics, School of Basic Medical Sciences, Tianjin Medical University, Tianjin 300070, China; \\ houxiaoyuan@tmu.edu.cn (X.H.); zsp@tmu.edu.cn (S.Z.); qixiaohui@tmu.edu.cn (X.Q.) \\ 2 Center for Applied Genomics, the Children's Hospital of Philadelphia, Philadelphia, PA 19104, USA; \\ quh@email.chop.edu (H.Q.); hakonarson@email.chop.edu (H.H.) \\ 3 Division of Human Genetics, Children's Hospital of Philadelphia, Philadelphia, PA 19104, USA \\ 4 Department of Pediatrics, the Perelman School of Medicine, University of Pennsylvania, \\ Philadelphia, PA 19104, USA \\ 5 Tianjin Eye Hospital, Tianjin 300020, China \\ 6 Tianjin Key Laboratory of Ophthalmology and Visual Science, Tianjin Eye Institute, Tianjin 300020, China \\ * Correspondence: qhxia@tmu.edu.cn (Q.X.); jli01@tmu.edu.cn (J.L.)
}

Received: 27 August 2020; Accepted: 9 October 2020; Published: 15 October 2020

\begin{abstract}
Juvenile idiopathic arthritis (JIA) is highly heterogeneous in terms of etiology and clinical presentation with ambiguity in JIA classification. The advance of high-throughput omics technologies in recent years has gained us significant knowledge about the molecular mechanisms of JIA. Besides a minor proportion of JIA cases as monogenic, most JIA cases are polygenic disease caused by autoimmune mechanisms. A number of $H L A$ alleles (including both $H L A$ class I and class II genes), and 23 non-HLA genetic loci have been identified of association with different JIA subtypes. Omics technologies, i.e., transcriptome profiling and epigenomic analysis, contributed significant knowledge on the molecular mechanisms of JIA in addition to the genetic approach. New molecular knowledge on different JIA subtypes enables us to reconsider the JIA classification, but also highlights novel therapeutic targets to develop a cure for the devastating JIA.
\end{abstract}

Keywords: epigenetics; genome-wide association study; genetics; juvenile idiopathic arthritis; transcriptome

\section{Introduction}

Juvenile idiopathic arthritis (JIA) is a common type of chronic rheumatic diseases affecting children with the age of onset under 16 years, and an important cause of disability. Epidemiological studies showed that incidence rate of JIA ranges from 1.6 to 23 per 100,000 children annually and the prevalence of JIA was about 3.8-400 per 100,000 children in Europe [1]. Girls exhibit a higher incidence rate than boys $(10.0 / 100,000$ compared to 5.7/100,000) [1]. Its negative effects on children's physical development, as well as psychiatric development, cause serious damage to the quality of life of affected children, causing pain of active joints, physical disability, anxiety, and depression. There is no cure for JIA. JIA needs aggressive treatment to control its symptoms. For this difficult disease, it is important to understand the underlying molecular mechanisms of the development of JIA systematically through unbiased approaches. In recent years, people have started to gain knowledge about the multiomics architecture of JIA, thanks to the advance of high-throughput omics technologies, which is the focus of this review article. 


\section{JIA as a Heterogeneous Group of Diseases}

JIA is a group of diseases, highly heterogeneous in terms of etiology and clinical presentation. It is classified into seven subtypes according to the Pediatric Task Force of the International League of Associations for Rheumatology (ILAR) [2], including systemic arthritis, oligoarthritis, polyarthritis RF-negative, polyarthritis RF-positive, psoriatic arthritis, enthesitis-related arthritis, and undifferentiated arthritis [2]. In terms of the seven subtypes of JIA, oligoarthritis is the largest category of JIA, accounting for $50-60 \%$ of all cases; the other subtypes' frequencies are, polyarthritis $(30-35 \%)$, systemic JIA (10-20\%), psoriatic arthritis (2-15\%), enthesitis-related arthritis (1-7\%) [3]. After 25 years since the clinical application of the ILAR classification, it is understood, to date, that some subtypes of JIA are highly heterogeneous, e.g., the polyarthritis RF-negative and psoriatic subtypes [4]. Ambiguity in classifying certain patients has also been an issue. Clinical efforts are currently being made to revise the ILAR classification [5].

\subsection{Systemic JIA (sJIA)}

Systemic JIA (sJIA) is defined as fever and arthritis that last for 2 weeks or more, with one or more of the following features: (1) transient erythema, (2) lymphadenopathy, (3) hepatomegaly or splenomegaly, and (4) serositis [6]. However, sJIA is often difficult to diagnose because its symptoms are nonspecific, and highly similar to other inflammatory diseases [7]. Due to the significant similarity with adult Still's disease, it seems correct to regard sJIA as juvenile onset Still's disease [4]. As a typical autoinflammatory disease, sJIA is considered as a polygenic disease as adult Still's disease [8], rather than a monogenic disease. Although commonly with fever and joint symptoms, almost all autoinflammatory diseases with a monogenic etiology, such as TNF receptor-associated periodic fever syndrome and juvenile sarcoidosis/Blau syndrome, have a narrowly defined spontaneous feature and systemic inflammation [9].

\subsection{Oligoarthritis and Polyarthritis}

The JIA subtypes, oligoarthritis and polyarthritis, are differentiated only by the number of affected joints. Oligoarthritis affects four or fewer joints during the first 6 months after the onset of the disease. The oligoarticular subtype of JIA is further divided into two subtypes: persistent oligoarthritis and extended oligoarthritis. For the former, the number of joints involved is limited to four or less during the whole disease process, while for the latter, the number of joints involved is more than four after 6 months of onset. Compared to oligoarthritis, polyarthritis affects five or more joints in the first 6 months of disease onset. According to the presence or absence of rheumatoid factor (RF), it is further divided into subtypes of RF positive and RF negative [6]. There are a lot of features in common between oligoarticular and polyarticular JIA, such as relatively good reactivity and benign prognosis [10].

\subsection{Psoriatic Arthritis}

Psoriatic arthritis is characterized by typical psoriatic rash or strong family history (first-degree relative) [2].

\subsection{Enthesitis-Related JIA}

Enthesitis-related JIA is defined as an arthritis or inflammation of the attachment point of tendons or ligaments, with at least two of the following symptoms: (1) sacroiliac tenderness or inflammatory lumbosacral and spinal pain, not limited to cervical; (2) HLA-B27 positive; (3) male children with symptoms older than eight years of age. (4) HLA-B27 related diseases in first degree relatives in family history $[2,6]$.

Undifferentiated arthritis, i.e., JIA patients cannot be assigned to one of the above JIA subtypes or can be assigned to more than one JIA subtype [2]. 


\section{Genetic Studies of Monogenic Forms of JIA}

Considering the poorly known etiologies of JIA and ambiguities of JIA classification, identification of monogenic forms of JIA has gained us significant knowledge on some critical molecular mechanisms (Table 1).

\section{1. $L A C C 1$}

FAMIN, encoded by the laccase domain containing 1 gene (LACC1), is an important protein in mitochondrial energy metabolism, related to the NOD2 pathway [11]. Recently, studies found that recessive hereditary LACC1/FAMIN mutations were correlated with different subtypes of monogenic JIA, including sJIA [12], oligoarthritis [12], polyarthritis RF-negative [13], and enthesitis-related arthritis [14]. The study using a combination of linkage analysis, homozygosity mapping, and whole-exome sequencing, discovered a homozygous mutation p.Cys284Arg (C284R) of LACC1 in every affected case of sJIA in five consanguineous families [15]. Besides C284R, the p.Ile254Val (I254V) mutation with important impact on FAMIN function [16], was implicated in nonsystemic forms of JIA [17]. Kallinich et al. found a novel homozygous frameshift mutation (p.T276fs*2) in two siblings with severe oligoarthritis [12]. The study on a Moroccan family with severe arthritis that presented recessive inheritance showed that the frame shift mutation of LACC1/FAMIN, p.Cys43Tyrfs* 6 , was most likely the cause of polyarthritis RF-negative JIA [13].

In a recent in vivo functional study on $L A C C 1$, Skon-Hegg et al. demonstrated the important role of LACC1 in inflammatory responses [18]. As shown in this study, LACC1 knockout mice showed worse disease in the Citrobacter rodentium model of colitis, and the collagen-induced arthritis models, compared to wild type (WT) mice, while there were no differences identified between LACC1 KO and WT in the dextran sulfate sodium (DSS) model of colitis and the $\mathrm{K} / \mathrm{BxN}$ model of arthritis [18]. Besides JIA, the pathogenic effects of LACC1 mutation I254V have been correlated with other diseases, e.g., inflammatory bowel disease [19], leprosy [20], and Behçet disease [21]. C284R was also identified of correlation with severe pediatric Crohn's disease in a Saudi family [15].

\section{2. $L R B A$}

The LPS responsive beige-like anchor protein gene (LRBA) encodes a member of the WDL-BEACH-WD (WBW) gene family, with its expression induced in B cells and macrophages by bacterial LPS [22]. LRBA protein helps to keep intracellular storage of cytotoxic T-lymphocyte-associated antigen 4 (CTLA-4) protein and prevents its degradation [23]. For activation of T lymphocytes, the T cell receptor (TCR) complex requires the costimulation by CD28 after antigen recognition [24]. CTLA-4 transmits inhibitory signals to attenuate $\mathrm{T}$ cell activation by competing for the B7 ligands with its homologue CD28 $[25,26]$. Reduced CTLA-4 activity is likely associated with JIA [27]. Meanwhile the expression of CTLA-4 in CD4+CD28- T-cells in JIA patients is increased in JIA patients and CD28-T cells are not susceptible to inhibition by CTLA-4 [28]. LRBA deficiency is a cause of common variable immunodeficiency (CVID), a group of congenital dysregulatory disorders in immune system. According to the study by Azizi et al., 10.1\% of 227 CVID patients show rheumatologic disorders, and JIA is the most common manifestation (3.1\%) [29]. Lopez-Herrera et al. reported for the first time that homozygous mutations of $L R B A$ correlated with common variable immunodeficiency- 8 with autoimmunity (CVID8) in four consanguineous families with CVID8 [30]. Semo Oz et al. reported a case of $L R B A$ deficiency who initially presented as polyarthritis and was diagnosed with JIA [31].

Gámez-Díaz et al. observed that Lrba knockout $\left(\mathrm{Lrba}^{-/-}\right)$mice showed reduced CTLA4 expression by Tregs and activated conventional CD4+ and CD8+ T lymphocytes, decreased frequency of peritoneal B-1a cells with reduced IL-10 production [32]. Lymphatic tissue showed no obvious signs of autoimmunity. The $\mathrm{Lrba}^{-/}$mice can produce a normal amount of serum IgM and IgG, generate specific antibody responses after immunization, and produce elevated serum and secretory basal IgA levels [32]. These findings expanded the roles of $L R B A$ protein in dysfunction of immune system, and suggested that $L R B A$ might be important for maintaining autoantigen tolerance. 
Table 1. The genes correlated with monogenic forms of juvenile idiopathic arthritis (JIA).

\begin{tabular}{|c|c|c|c|c|}
\hline Genes & Causal Mutations (PMID) & Related Subtype of JIA & Functional Evidence (PMID) & Mechanism \\
\hline LRBA & & Oligoarthritis & $\begin{array}{l}\text { Lrba }^{-/} \text {mice produce high levels of } \\
\text { serum and secretory IgA (28652580). }\end{array}$ & $\begin{array}{l}\text { Defects in peripheral } \\
\text { tolerance. }\end{array}$ \\
\hline NFIL3 & p.M170I (30552177) & systemic JIA & $\begin{array}{l}\text { NFIL3 mutations drive elevated } \\
\text { IL-1 } \beta \text { (30552177) }\end{array}$ & $\begin{array}{l}\text { Sensitizing for arthritis. } \\
\text { Development and rewiring } \\
\text { the innate immune system for } \\
\text { IL-1 overproduction }\end{array}$ \\
\hline LACC1 & $\begin{array}{c}\text { p.Cys284Arg (27881174) } \\
\text { p.Ile254Val (27881174) } \\
\text { rs3816311 (27098602) } \\
\text { p.Arg414Ter (2917096) } \\
\text { p.Ile330del (2917096) } \\
\text { p.Cys43Tyrfs* } 6(30872671)\end{array}$ & systemic JIA & $\begin{array}{c}\text { TNF levels were increased in } \\
\text { LACC } 1^{-/-} \text {mice. } \\
\text { LACC1 transcripts } \\
\text { and protein were upregulated by LPS } \\
\text { and other TLR ligands in } \\
\text { macrophages and dendritic } \\
\text { cells }(30510070) .\end{array}$ & Regulating inflammation. \\
\hline UNCD13 & $\begin{array}{c}\text { c. } 117+143 \mathrm{~A}>\mathrm{G}(29409136) \\
753+3[\mathrm{G}>\mathrm{A}](18240215) \\
1579[\mathrm{C}>\mathrm{T}] \mathrm{R} 527 \mathrm{~W}(18240215)\end{array}$ & systemic JIA & $\begin{array}{l}\text { Munc13-4 was highly expressed in } \\
\text { differentiated human NK cells and } \\
\text { effector CD8+ T lymphocytes. } \\
\text { Munc13-4 expression levels were } \\
\text { selectively upregulated upon cytotoxic } \\
\text { lymphocyte differentiation (24842371). }\end{array}$ & $\begin{array}{l}\text { Disrupting transcription } \\
\text { factor binding. }\end{array}$ \\
\hline
\end{tabular}

SYS: systemic arthritis; OLG: oligoarthritis; JIA: juvenile idiopathic arthritis. 


\subsection{NFIL3}

The nuclear factor, interleukin 3 regulated gene (NFIL3) encodes an important transcription factor in human immune system, regulating cytokine production of type $2 \mathrm{~T}$ helper $(\mathrm{T}(\mathrm{H}) 2)$ cells [33]. Research found that the expression of NFIL3 is impaired in Crohn's disease and ulcerative colitis patients, which may shift tolerogenic functions of macrophages to proinflammatory [34]. Schlenner et al. studied two monozygotic twin girls with JIA, using whole exome sequencing, single cell sequencing, and flow cytometry [35]. A novel homozygous mutation, methionine to isoleucine mutation at residue 170 (M170I) in NFIL3, was identified in the patients [35]. The mutation reduced stability of NFIL3 protein. Nfil3-knockout mice had upregulated IL-1 $\beta$ production, and increased susceptibility to arthritis induction [35].

\subsection{UNC13D}

The unc-13 homolog D gene (UNC13D) encodes a protein essential for cytolytic granules secretion at the immunologic synapse [36]. Partial knockdown expression of UNC13D resulted in impaired NK cell degranulation [37]. Schulert et al. reported an intronic mutation in UNC13D, c.117 + 143A > G in a patient with sJIA and recurrent MAS [37]. This mutation is located in a region regulating lymphocyte-specific UNC13D expression, disrupted the binding of NF- $\mathrm{kB}$ with a transcriptional enhancer, and is associated with downregulated transcription of UNC13D in PBMCs. A previous study also reported genetic association between the MUNC13-4 (UNC13D) sequence polymorphisms and sJIA/macrophage activation syndrome (MAS) [38]. Hazen et al. reported compound heterozygous mutations of UNC13D correlated with systemic JIA without MAS in an 8-year-old girl with decreased cytotoxic function of NK cells [39].

\section{Genetic Studies of Polygenic Forms of JIA}

Besides the above monogenic forms of JIAs, JIA is commonly considered as an immune disorder caused by complex interactions between environmental factors and multiple genetic risk factors [40]. Early studies revealed that siblings or twins of JIA patients have an increased risk up to $15-30 \%$, which is close to that of type 1 diabetes [41]. The age of onset and disease duration among JIA twins are highly consistent, suggesting JIA as a polygenic genetic disease [40].

In recent years, numerous susceptibility loci have been identified through genome-wide association studies (GWAS) of autoimmune diseases. With the application of molecular genetic and genomic technologies in JIA research, some disease-causing genetic variants have been identified in JIA families [42]. Although some risk variants are located in coding regions of genes affecting protein structure and leading to prominent clinical significance, a larger number of risk variants are mapped to noncoding regions containing regulatory elements, which may have an impact on chromatin structure or noncoding RNA binding, and affect gene expression in a tissue-specific or disease state-related manner [42]. The functional genes in these loci have significantly increased the knowledge about the pathogenesis underlying this complex disease.

\subsection{The Association with HLA}

Among the identified JIA genetic loci, the human leukocyte antigen locus (HLA) confers the strongest effect in JIA genetic susceptibility because of its major roles in autoimmune destruction (Table 2) [43]. The HLA genes locate at Chr6p21.3, including HLA class I and class II genes. Antigens presented by HLA class I molecules are of intracellular origin, while antigens presented by HLA class II molecules are from extracellular proteins. The HLA proteins are by far the most polymorphic products encoded by the human genome. Multiple amino acid variations have been driven by the evolutionary advantage of heterozygosity, allowing the presentation of diverse antigens from emerging pathogens, despite increased risk of many polygenic diseases [44]. 
Table 2. HLA alleles associated with JIA subtypes.

\begin{tabular}{|c|c|c|}
\hline Subtype of JIA & Predisposing Allele & Protective Allele \\
\hline $\begin{array}{l}\text { Oligoarthritis and polyarthritis } \\
\text { RF-negative }\end{array}$ & $\begin{array}{c}\text { A2, DRB1*01,DRB1*08, DRB1*11, } \\
\text { DRB1*13,DPB1*02,DPB1*03, DQB1*04, }\end{array}$ & DRB1*04, DRB1*07,DRB1*15:01 \\
\hline Polyarthritis RF-positive & DRB1*04:01,DRB1*04:05 & \\
\hline Systemic JIA & HLA-DRB1*11 & \\
\hline Enthesitis-related JIA & 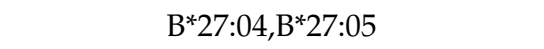 & \\
\hline
\end{tabular}

\subsubsection{Oligoarthritis and Polyarthritis RF-Negative}

In the past few decades, studies have provided multiple lines of evidence that polyarthritis RF-negative subtype has a strong association with $H L A$ Class II alleles DRB1*08 and DPB1*03, and HLA Class I allele $A 2[45,46]$. Oligoarthritis is also associated with $D P B 1^{*} 02, D Q B 1^{*} 04, D R B 1^{*} 01$, $D R B 1^{*} 08, D R B 1^{*} 11$, and DRB1*13 [47,48]. DRB1*11:03/11:04 and DRB1*08:01 confer susceptibility to both oligoarthritis and polyarthritis RF-negative JIA patients [49]. Interestingly, $D R B 1^{*} 04$ and $D R B 1^{*} 07$ confer a very strong protective effect to oligoarthritis and $D R B 1^{*} 15: 01$ is protective against both oligoarthritis and polyarthritis RF-negative [49,50]. Fine-mapping the HLA locus in JIA reveals that extended oligoarthritis and the RF-negative polyarthritis are genetically similar in their HLA associations [51]. HLA-DRB1 amino acid position 13 showed the strongest connection with oligoarthritis and both RF-positive and RF-negative polyarthritis [51].

\subsubsection{Polyarthritis RF-Positive}

There have been many earlier studies focusing on the connection between polyarticular RF-positive JIA and HLA [52-55]. Examination of the genotypes of JIA patients by PCR-sequence-specific oligonucleotide probe methodology has shown that $H L A-D R B 1^{*} 04: 05$ is associated with polyarthritis RF-positive [56]. Within the HLA region, the most significant locus is rs3129769. This locus is near HLA-DRB1, and in a strong linkage disequilibrium $\left(\mathrm{r}^{2}=0.88\right)$ with the SNP rs660895 reported in rheumatoid arthritis (RA) $[57,58]$. These SNPs map to the HLA-DRB1*0401 allele.

\subsubsection{SJIA}

As the one of the common subtypes, accounting for 10-20\% of all JIA, knowledge on the pathogenesis of sJIA is still lacking. As the patients with sJIA present with prominent systemic symptoms, such as fever, rash, and synovitis, activation of the autoimmune system is suggested. However, any association between autoantibodies and HLA in sJIA is still lacking [59]. Research to date shows that HLA class II alleles are significantly associated with sJIA [60]. Meta-analysis of six populations with Western European ancestries showed that HLA-DRB1*11 had strong association [60]. The SNP rs151043342 had the strongest association with sJIA among 482 sJIA-associated SNPs in the class II HLA region [60].

\subsubsection{Psoriatic and Enthesitis-Related JIA}

$H L A-B 27$ has been discovered in 60 90\% enthesitis-related JIA patients [61]. By assessing the prevalence of $H L A-B 27$ in enthesitis-related JIA and other subtypes of JIA in an Asian-Indian population, the prevalence of $H L A-B 27$ was highest in the enthesitis-related JIA group (87\%) [62]. In 160 patients of South Indian Tamil with enthesitis-related JIA, Kavadichanda et al. found that $H L A-B^{*} 27$ was positive in $109(68.1 \%)$ patients [63]. Among the $H L A-B^{*} 27$ positive patients, $H L A-B^{*} 27: 04$ was discovered in $62.5 \%$ patients, followed by $B^{*} 27: 05$ in $30.2 \%$ patients [63]. Similar clinical phenotypes were seen in both $H L A-B^{*} 27: 04$ and ${ }^{*} 27: 05$ positive patients [63]. Similar results were reported by Shih et al. in a population from Taiwan. Shih et al. conducted a retrospective review in enthesitis-related JIA patients admitted to the National Taiwan University Hospital during 1993-2018. In total, 97\% of patients were $H L A-B 27$-positive $\left(92 \%\right.$ were $B^{*} 27: 04$ and $8 \%$ were $\left.B^{*} 27: 05\right)$ [64]. In contrast, $H L A-B^{*} 27: 05$ 
was more frequent than $H L A-B^{*} 27: 04$ in a northern India population with enthesitis-related JIA, whereas $H L A-B^{*} 27: 05$ was also suggested as the ancestral and disease-predisposing allele [65].

\subsection{Association with Non-HLA Loci}

To date, many studies have been performed to test the association between JIA and functional candidate genes with known biological functions or associations with other autoimmune diseases, such as rheumatoid arthritis (RA) and type 1 diabetes (T1D). In addition, a number of JIA-associated non-HLA loci have been identified through the unbiased approach of genome-wide association studies (GWAS). Most of these loci are located at noncoding regions, about a half of which overlap with adult-onset arthritis [42,66].

Due to the low prevalence of JIA, sample size has been a major limitation for GWASs on JIA. To increase the sample size, several GWASs have been conducted with a cohort of mixed JIA subtypes. In the first GWAS on JIA, 279 cases (including $48 \%$ persistent oligoarthritis, $29 \%$ extended oligoarthritis, 20\% RF-negative polyarthritis, and 3\% RF-positive polyarthritis) and 184 controls were studied. Besides the most strongly associated SNP (rs2187684) mapped to the HLA region, Hinks et al. identified a significantly associated SNP (rs2358820) located within the gene VTCN1, which encodes a negative regulator of T-cell mediated immune responses [67]. By fine-mapping of the VTCN1 locus, Hinks et al. identified 10 SNPs associated with JIA [67]. Consequently, a GWAS including 388 children with JIA cases and 2500 controls with European ancestry replicated three previously reported loci mapped to the genes PTPN22, IL2RA, and ANTXR2. Besides, they identified a novel locus with the peak SNP (rs953387), an expression quantitative trait locus (eQTL) associated with the expression level of CXCR4 in T-cells $(p=0.0054)$ and lymphoblastoid cells $(p=0.014)$ [68]. They also observed four rare variants existed only in JIA patients, not in controls.

The protein tyrosine phosphatase non-receptor type 22 gene (PTPN22) variants have been identified of association with JIA and many other autoimmune diseases [69]. PTPN22 encodes a protein tyrosine phosphatase, which is mainly expressed in cytoplasm of hematopoietic origin cells. The proteins PTPN22, SHP-1 (PTPN6), and PTPN2 may limit TCR proximal signaling by dephosphorylation of Lck Y394 (a key tyrosine residues of Src family) in T-cells [70,71]. Previous studies showed that the counts of effector/memory T-cells increased in Ptpn 22 deficient mice, compared with wild-type mice during rest state, but had no influence on naïve T cells [72,73]. Consistently, PTPN22 expression has been shown elevated in effector and memory T-cells, relative to naïve T-cells [74,75]. PTPN22 may thus be important for the regulation of effector but not naïve T-cell activation.

To date, 23 JIA loci, harboring 33 genes, outside of the HLA region have been identified with genome-wide significance (Table 3). To systematically examine potential pleiotropic effects of genes associated with different autoimmune diseases, Li et al. conducted a meta-analysis on GWASs of 10 different pediatric-age-of-onset autoimmune diseases [76]. SNPs at seven loci of ADGRL2, PTPN22, TENM3, ANKRD55, IL2RA, IL21, and ANKRD30A, were identified of association with both JIA and other autoimmune diseases, such as common variable immunodeficiency (CVID), autoimmune thyroiditis (THY), ankylosing spondylitis (AS), celiac disease (CEL), ulcerative colitis (UC), Crohn's disease (CD), and systemic lupus erythematosus (SLE), although some loci with opposite direction of effect [76]. The genes at JIA GWAS loci are enriched in signaling pathways playing key roles in both innate immune responses and adaptive immunity, showing interactions with each other (Figures 1 and 2). 
Table 3. Genome-wide significant loci (non-HLA) associated with JIA summarized in GWAS Catalog (https://www.ebi.ac.uk/gwas/). JIA associated SNPs listed in GWAS catalog were clumped into independent loci based on the linkage disequilibrium and distance between SNPs.

\begin{tabular}{|c|c|c|c|c|c|c|c|c|c|c|c|}
\hline Index SNPs & Chr & Position & Region & $\begin{array}{c}\text { Ref } \\
\text { Allele }\end{array}$ & $\begin{array}{c}\text { Risk } \\
\text { Allele }\end{array}$ & $\begin{array}{c}\text { Mapped } \\
\text { Gene }\end{array}$ & $\begin{array}{l}\text { Risk Allele } \\
\text { Frequency }\end{array}$ & $p$-Value & $\begin{array}{l}\text { Odds } \\
\text { Ratio }\end{array}$ & $\begin{array}{l}\text { Associated } \\
\text { JIA Subtypes }\end{array}$ & PMID \\
\hline rs72632736 & 1 & 4389144 & $1 \mathrm{p} 36.32$ & A & G & EEF1DP6-LINC01777 & & $3.00 \mathrm{E}-09$ & 2.4 & SYS & 27927641 \\
\hline rs2066363 & 1 & 81771892 & $1 \mathrm{p} 31.1$ & C & $\mathrm{T}$ & ADGRL2 & 0.34 & $8.00 \mathrm{E}-11$ & & & 26301688 \\
\hline rs6679677 & 1 & 113761186 & $1 \mathrm{p} 13.2$ & $\mathrm{C}$ & $\mathrm{A}$ & PHTF1-RSBN1 & 0.10 & $3.00 \mathrm{E}-25$ & 1.59 & OLG,PRFN & 23603761 \\
\hline rs6679677 & 1 & 113761186 & $1 \mathrm{p} 13.2$ & $\mathrm{C}$ & $\mathrm{A}$ & PHTF1-RSBN1 & 0.09 & $8.00 \mathrm{E}-11$ & & & 26301688 \\
\hline rs72698115 & 1 & 154406893 & $1 \mathrm{q} 21.3$ & $\mathrm{~A}$ & C & $I L 6 R$ & 0.1 & $1.00 \mathrm{E}-08$ & 1.36 & OLG,PRFN & 23603761 \\
\hline rs10174238 & 2 & 191108308 & $2 q 32.3$ & G & A & STAT4 & 0.23 & $1.00 \mathrm{E}-13$ & 1.29 & OLG,PRFN & 23603761 \\
\hline rs1479924 & 4 & 122466445 & $4 q 27$ & G & A & IL2-IL21 & 0.71 & $6.00 \mathrm{E}-11$ & 1.27 & OLG,PRFN & 23603761 \\
\hline rs62324212 & 4 & 122639784 & $4 \mathrm{q} 27$ & $\mathrm{C}$ & $\mathrm{A} / \mathrm{G}$ & IL21-AS1 & 0.42 & $3.00 \mathrm{E}-08$ & & & 26301688 \\
\hline rs7660520 & 4 & 182824168 & $4 q 35.1$ & G & $\mathrm{A} / \mathrm{C}$ & TENM3-AC114798.1 & 0.26 & $8.00 \mathrm{E}-11$ & & & 26301688 \\
\hline rs10213692 & 5 & 56146422 & $5 q 11.2$ & $\mathrm{~T}$ & $\mathrm{C} / \mathrm{T}$ & ANKRD55 & 0.75 & $3.00 \mathrm{E}-11$ & 1.27 & OLG,PRFN & 23603761 \\
\hline rs7731626 & 5 & 56148856 & $5 q 11.2$ & G & A & ANKRD55 & 0.39 & $1.00 \mathrm{E}-10$ & & & 26301688 \\
\hline rs27293 & 5 & 97021474 & $5 q 15$ & A & $\mathrm{G} / \mathrm{T}$ & LNPEP & 0.44 & 7.00E-09 & 1.31 & OLG,PRFN & 23603761 \\
\hline rs6894249 & 5 & 132461855 & $5 q 31.1$ & $\mathrm{~A}$ & G & AC116366.3, C5orf56 & 0.61 & $1.00 \mathrm{E}-09$ & 1.32 & OLG,PRFN & 23603761 \\
\hline rs6946509 & 7 & 22769871 & $7 \mathrm{p} 15.3$ & $\mathrm{~T}$ & $\mathrm{~A} / \mathrm{C}$ & МТС ҮВР $42-A C 073072.2$ & 0.45 & $3.00 \mathrm{E}-08$ & 1.19 & OLG,PRFN & 23603761 \\
\hline rs7909519 & 10 & 6047878 & $10 \mathrm{p} 15.1$ & $\mathrm{~T}$ & G & $I L 2 R A$ & 0.89 & $8.00 \mathrm{E}-10$ & 1.39 & OLG,PRFN & 23603761 \\
\hline rs706778 & 10 & 6056986 & $10 \mathrm{p} 15.1$ & $\mathrm{C}$ & $\mathrm{T}$ & $I L 2 R A$ & 0.41 & $6.00 \mathrm{E}-09$ & & & 26301688 \\
\hline rs7100025 & 10 & 37303610 & $10 \mathrm{p} 11.21$ & G & $\mathrm{A}$ & LINC00993, ANKRD30A & 0.34 & $8.00 \mathrm{E}-11$ & & & 26301688 \\
\hline rs7069750 & 10 & 89002619 & $10 \mathrm{q} 23.31$ & $\mathrm{G}$ & $\mathrm{C} / \mathrm{T}$ & FAS & 0.44 & $3.00 \mathrm{E}-08$ & 1.18 & OLG,PRFN & 23603761 \\
\hline rs7127214 & 11 & 36322143 & $11 \mathrm{p} 13$ & $\mathrm{C}$ & $\mathrm{G} / \mathrm{T}$ & PRR5L, AC087277.1 & 0.65 & $2.00 \mathrm{E}-08$ & 1.28 & OLG,PRFN & 23603761 \\
\hline rs10849448 & 12 & 6384185 & 12p13.31 & A & G & LTBR & 0.24 & $5.00 \mathrm{E}-09$ & 1.24 & OLG,PRFN & 23603761 \\
\hline rs7137828 & 12 & 111494996 & $12 \mathrm{q} 24.12$ & C & $\mathrm{A} / \mathrm{T}$ & ATXN2 & 0.49 & $2.00 \mathrm{E}-09$ & 1.20 & OLG,PRFN & 23603761 \\
\hline rs3825568 & 14 & 68793871 & $14 \mathrm{q} 24.1$ & $\mathrm{C}$ & $\mathrm{G} / \mathrm{T}$ & ZFP36L1 & 0.56 & $1.00 \mathrm{E}-08$ & 1.30 & OLG,PRFN & 23603761 \\
\hline rs2847293 & 18 & 12782449 & $18 \mathrm{p} 11.21$ & A & $\mathrm{G} / \mathrm{T}$ & AP005482.1-PTPN2 & 0.17 & $1.00 \mathrm{E}-12$ & 1.31 & OLG,PRFN & 23603761 \\
\hline rs34536443 & 19 & 10352442 & $19 \mathrm{p} 13.2$ & G & C & TYK2 & 0.95 & $1.00 \mathrm{E}-10$ & 1.79 & OLG,PRFN & 23603761 \\
\hline rs8129030 & 21 & 35340290 & $21 \mathrm{q} 22.12$ & $\mathrm{~T}$ & $\mathrm{~A} / \mathrm{G}$ & RUNX1 & 0.63 & $5.00 \mathrm{E}-09$ & 1.28 & OLG,PRFN & 23603761 \\
\hline rs2266959 & 22 & 21568615 & $22 q 11.21$ & G & $\mathrm{T}$ & UBE2L3 & 0.19 & $6.00 \mathrm{E}-09$ & 1.24 & OLG,PRFN & 23603761 \\
\hline rs2284033 & 22 & 37137994 & $22 \mathrm{q} 12.3$ & G & A & $I L 2 R B$ & 0.56 & $2.00 \mathrm{E}-08$ & 1.19 & OLG,PRFN & 23603761 \\
\hline
\end{tabular}

PRFN, polyarthritis RF negative; OLG, oligoarthritis; SYS, systemic arthritis; JIA, juvenile idiopathic arthritis. 


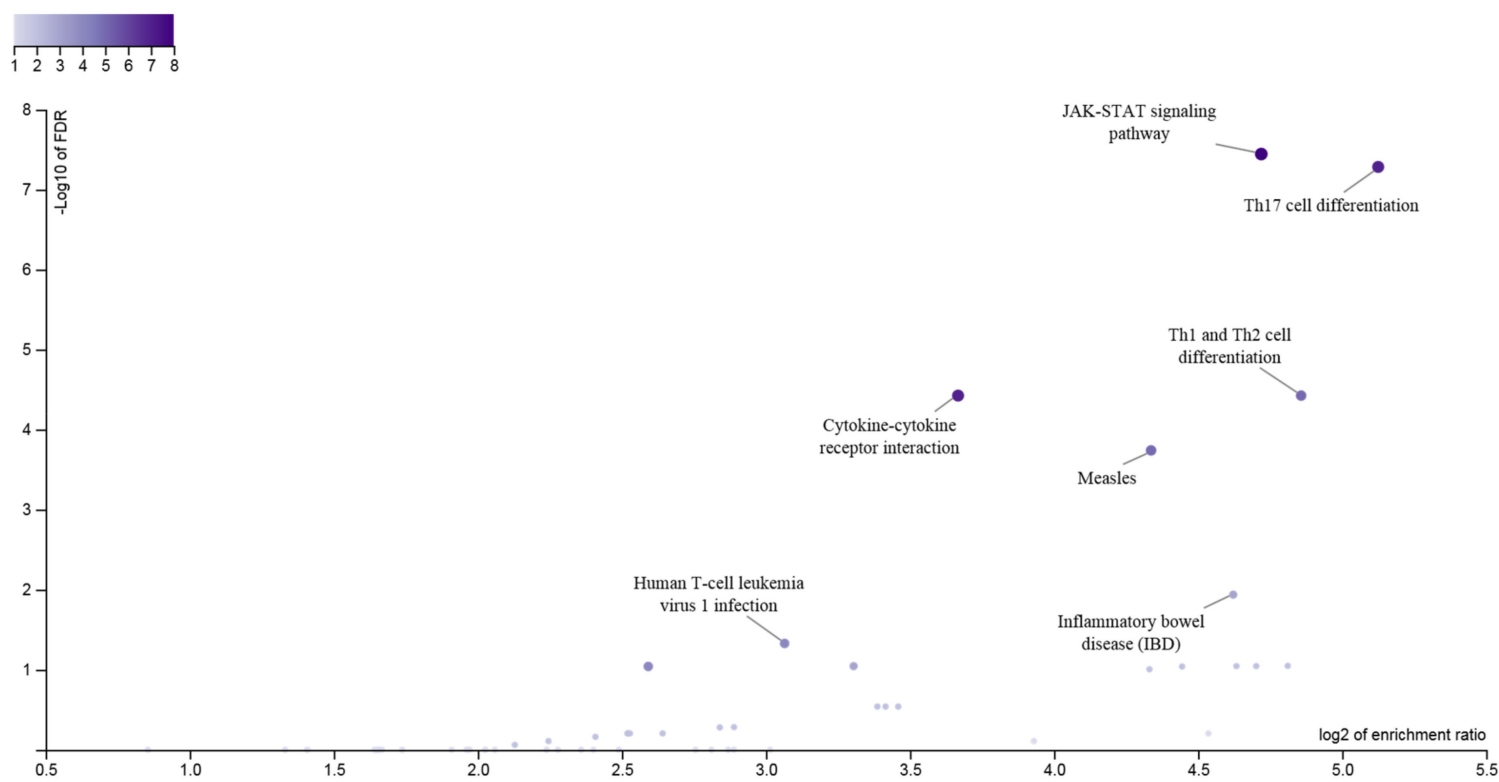

Figure 1. Pathway analysis of 33 genes at the JIA GWAS loci. The enrichment ratio for the functional categories in the KEGG database is shown on the X-axis and the log of the FDR is shown on the $Y$-axis, indicating the degree by which the significant categories stand out from the background. The size and color of the dot are proportional to the number of input genes falling into each pathway.

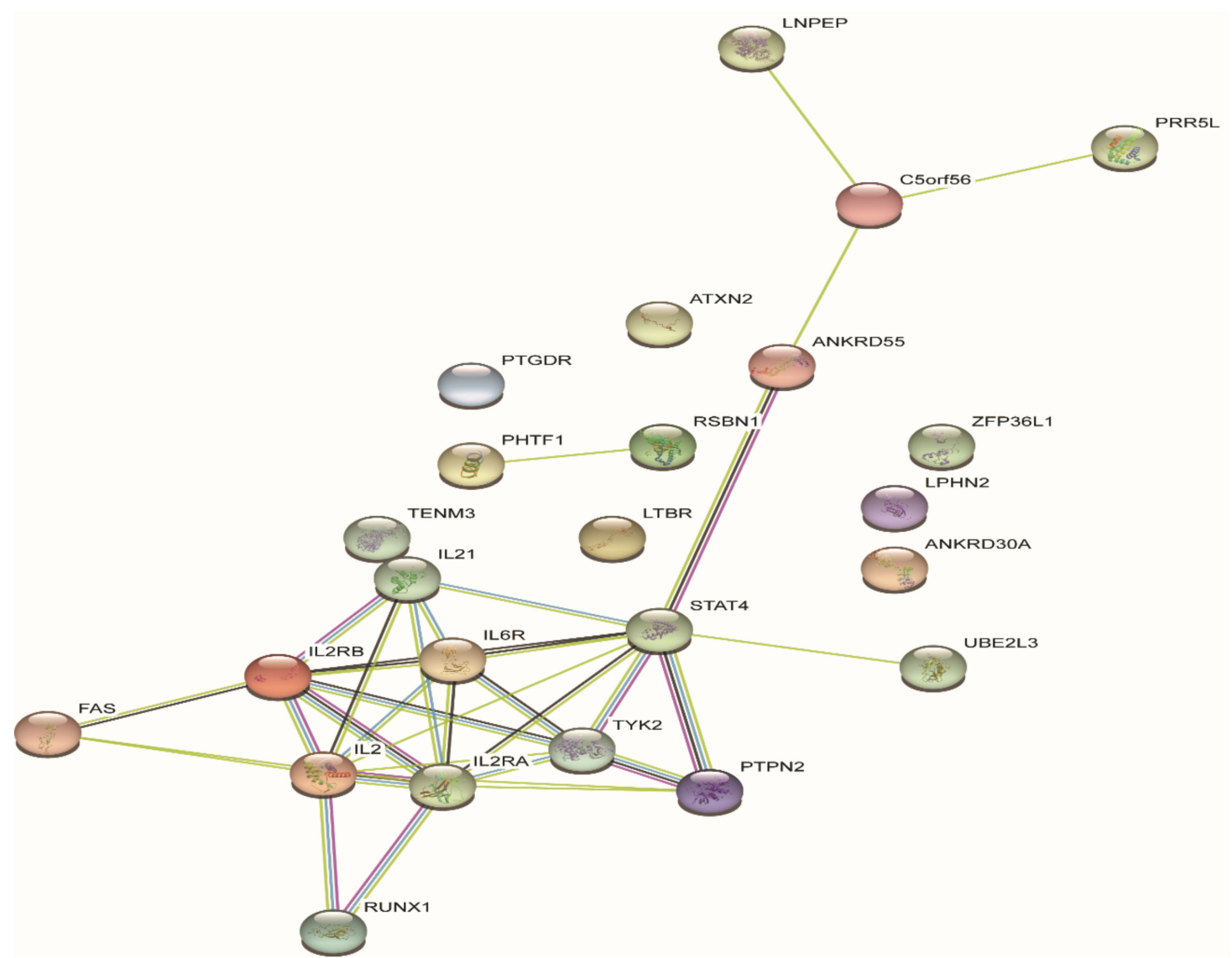

Figure 2. Protein-protein interaction (PPI) analysis of the 33 genes in the GWAS loci. Each node represents each gene product at the JIA GWAS loci and edges between nodes represent protein-protein interactions. 


\subsubsection{Oligoarthritis and Polyarthritis RF Negative}

Four previously reported loci of autoimmune diseases, including PTPN22 (rs6679677, rs2476601, rs2488457), STAT4 (rs3821236, rs7574865), C12orf30, and ADAD1-IL2-IL21 (rs17388568, rs13143866), and three novel loci including PTPN2 (rs1893217, rs7234029), COG6 (rs7993214), and ANGPT1 (rs1010824), were identified of association with oligoarthritis and polyarthritis RF-negative [77]. This study included 809 oligoarthritis and polyarthritis RF-negative cases and 3535 controls of non-Hispanic European population. Consequently, this group proved the relationship between oligoarthritis and polyarthritis RF-negative by sharing common genetic susceptibility loci, including C12orf30 (rs17696736), C3orf1, and CD80 at chr3q13 (rs4688011), JMJD1C (rs6479891, rs12411988, and rs10995450) [78]. These SNPs have been identified of association with other autoimmune diseases such as RA, T1D, Crohn's disease, and multiple sclerosis.

In the largest GWAS on JIA to date, Hinks et al. identified 14 novel JIA susceptibility loci with genome-wide significance $\left(p<5 \times 10^{-8}\right)$ by genotyping 2816 JIA cases with European ancestry (including both oligoarthritis and polyarthritis RF-negative patients) and 13,056 controls with the Illumina Infinium Immunochip [42]. The Immunochip provides cost-effective genotyping solution for both common and rare variants as a helpful tool for immunogenetic study. The Immunochip is suitable to conduct replication of autoimmune and inflammatory diseases, and to fine-map established GWAS loci [79]. Another GWAS study on JIA with a large sample size, including 2751 oligoarthritis and polyarthritis RF-negative patients and 15,886 controls, replicated nine previously reported GWAS loci, and suggested five additional loci with $p<1 \times 10^{-6}$, i.e., PRR9_LOR, ILDR1_CD86, RNF215, LINC00951, and HBP1, but none of these loci reached genome-wide significance [80].

Among the GWAS loci, CD86 and JAK1 are important for signaling pathways of T cell differentiation and proliferation [81]. Many of the oligoarthritis and polyarthritis RF-negative GWAS loci were shared with other autoimmune diseases, suggesting pleiotropic effects of these loci as well as shared molecular mechanisms of autoimmune diseases, such as T-cell receptor activation and signaling. For example, these JIA associated loci have been identified of association with other autoimmune diseases: JAK1 with CEL and multiple sclerosis (MS); PTH1R with CEL; AHI1_LINC00271 with CEL, MS, THY, and T1D; WDFY4 with SLE.

Zervou et al. investigated the nonsynonymous SNP rs34536443 on TYK2 [82], which has been shown of association with various rheumatic diseases. The SNP results in amino acid substitution of Pro1104 to Ala. The study found that the SNP led to the extension of the $\alpha$-helical segment and alternation of the protein 3D structure, which is likely to affect the function of the TYK2 protein [82]. Couturier et al. performed a study on the association between TYK2 polymorphism and multiple sclerosis in 1366 French patients and 1802 matched controls [83]. The study found that the protective genotype of the TYK2 polymorphism rs34536443 may reduce the activity of TYK2, which may promote the secretion of Th2 cytokines and induce T lymphocyte differentiation toward a Th2 phenotype [83]. These functional effects of TYK2 polymorphism may explain its association with oligoarthritis and polyarthritis RF-negative JIA [42].

\subsubsection{Polyarthritis RF-Positive}

Some children with polyarthritis RF-positive JIA have the phenotypes of chronic inflammatory arthritis and one or more positive tests of RF and/or anti-citrullinated peptide antibodies (ACPA) [84]. These phenotypes are similar to adult-onset RA. Polyarthritis RF-positive JIA is likely to share clinical features, pathogenesis, and genetic/environmental factors with RA in adults. Previous candidate gene association studies have shown that polyarthritis RF-positive JIA is associated with adult RA-associated loci, i.e., rs10499194 (TNFAIP3), rs2476601 (PTPN22), and rs7574865 (STAT4) [85]. Furthermore, large sample studies on polyarthritis RF-positive provide solid evidence that this infrequent subtype of JIA not only has a lot in common with adult seropositive RA in phenotype, but also has more in common with adult RA in genetics than the other subtypes of JIA. 
Hinks et al. recruited 340 polyarthritis RF-positive JIA patients and 14,412 controls from US, UK, Germany, Canada, and Norway, and genotyped these participants using the Immunochip array [57]. This study assessed 44 previously reported non-HLA loci associated with RA, and 27 oligoarthritis/polyarthritis RF-negative JIA loci, to see if these loci were associated with polyarthritis RF-positive JIA in this population. In total, 19 of 44 RA risk loci showed significant association with polyarthritis RF-positive (23 polyarthritis RF-positive associated loci in total) $[57,66]$. On the other hand, only three of 44 RA risk loci showed significant association with oligoarthritis and polyarthritis RF-negative (27 oligoarthritis/polyarthritis RF-negative associated loci in total) $[57,66]$. This study provided convincing evidence that polyarthritis RF-positive JIA is more similar to adult RA in genetic architecture than oligoarthritis and polyarthritis RF-negative JIA. In contrast, six loci were shared by polyarthritis RF-positive (out of 23 loci) and oligoarthritis/polyarthritis RF-negative JIA (out of 27 loci) [57].

\subsubsection{SJIA}

No reported genetic risk factors have been shared by sJIA and other JIA subtypes, suggesting that sJIA may have a special disease process which distinguishes it from other types of JIA. Many candidate gene studies reported sJIA association of a number of SNPs at different genetic loci, such as IL6 [86,87], MIF [88,89], IL10/20 [90,91], IL1 [92,93], MVK, TNFRSF1A [93], CCR5 [94], SLC26A2 [95,96], and TPSN [96], etc. The first GWAS on sJIA included 982 sJIA cases and 431 controls from nine countries [97]. Besides the HLA locus, a novel locus at chr1p36.32 was reported of sJIA association with genome-wide significance (GWS). This locus contains 14 SNPs with GWS, while the index SNP rs72632736 is mapped $263.5 \mathrm{~kb}$ upstream of the adherens junction-associated protein 1 gene (AJAP1) [97], which plays a role in cell adhesion and cell migration [98]. The sJIA GWAS also observed 23 novel loci with suggestive evidence $\left(p<5 \times 10^{-6}\right)$, and found no overlapped genetic loci between sJIA and other common subtypes of JIA [97]. More notably, they found treatment-related susceptibility loci in sJIA, i.e., the HLA class II locus. The HLA class II molecules may result in activation of CD4+ T cells. Abatacept has shown promising therapeutic effect particularly in refractory cases with sJIA $[99,100]$ by reducing T-cell activation through costimulatory inhibition.

According to the study by Arthur et al. [101], a SNP in the promoter region of IL1RN was associated with sJIA. In addition, many of the top sJIA-associated SNPs were correlated with IL1RN expression in lymphoblastoid cell lines. It has been observed in sJIA patients that homozygotes of alleles with higher expression of IL1RN have strong association with non-response to anakinra therapy. This discovery has important implications in precision treatment of sJIA.

\section{Transcriptome Study of JIA}

Transcriptome study has demonstrated the important roles of specific cell types in JIA pathogenesis of different subtypes, clinical remission, and response to treatment. Differential gene expression analysis uncovered a gradient of order among the JIA subtypes, from healthy controls, to oligoarticular, polyarticular, and sJIA, to Crohn's disease [102]. Approximately 246 genes were identified as significantly upregulated in patients with active sJIA [103], including IL-6 expressed in monocytes and B cells, IL-10 in monocytes, and suppressor of cytokine signaling 3 (SOCS3) in monocytes and T cells. Cell type analyses allow further probe into the pathogenic mechanisms. Hierarchical clustering suggested the division of polyarticular JIA into three distinct subsets [104]. The three subgroups were associated with different monocyte markers, transforming growth factor $\beta$ (TGF- $\beta$ )-inducible genes, and immediate early genes, respectively.

\subsection{Transcriptome Profiling of Neutrophils in JIA}

Ter Haar et al. showed that neutrophils played an important role in the early inflammatory phase of sJIA, and the number and inflammatory activity of neutrophils were highly sensitive to the blockade of IL-1 signaling [105]. To examine activated neutrophil subsets, Brown et al. isolated neutrophils from 
children with active sJIA or clinically inactive disease (CID) [106]. In both groups, neutrophils from sJIA patients exhibited increased S100A8/A9 release upon PMA stimulation compared to control neutrophils. The study also showed that the number of suppressive neutrophils CD16 + CD62 $^{\text {lo }}$ increased with nuclear hypersegmentation in the children with sJIA. Transcriptome analysis of purified neutrophils showed that the genes AIM2, IL18RAP, and NLRC4, involved in critical immune system processes were significantly upregulated [106]. These studies increased our understanding on the roles of neutrophils in sJIA.

\subsection{Transcriptome Profiling of Macrophages in JIA}

CD163, a hallmark of macrophage activation [107], is highly expressed in macrophages of patients with active sJIA or macrophage activation syndrome (MAS) [108]. Two microRNAs, miR-125a-5p and miR-181c, which were previously found to be elevated in active sJIA [109], may reduce CD163 expression of macrophages. Both microRNAs were not elevated in macrophages with stable CD163 expression, but were induced in macrophages with increased CD163 mRNA expression. The miR-181s may target directly at CD163 mRNA for degradation. Overexpression of miR-181c inhibits the anti-inflammatory response of CD163 to hemoglobin or the high-mobility box 1 complex [110]. In contrast, transcriptome analysis of miR-125a-5p overexpression identified "cytokine-cytokine receptor interactions" as the most significantly inhibited gene pathway with reduced interleukin 10 Receptor Subunit Alpha (IL10RA), while IL-10 mediation is required for CD163 expression [108].

\subsection{Transcriptome Profiling of Monocytes in JIA}

Comparing JIA patients with controls, CXCL8 (IL-8) was the most significantly expressed gene transcript [111]. The difference in clinical response to methotrexate in patients with JIA was related to the difference in a number of gene transcripts regulated in monocytes [111]. These gene expression profiles could provide the basis for predicting biomarkers of response to methotrexate treatment [111].

\subsection{Transcriptome Profiling of T Cells in JIA}

CD27, CD276, CTLA4, IL2RG, and SLAMF7 are significantly upregulated in patients with sJIA-related lung diseases, suggesting the activation of T cells [112]. By the transcriptome analysis of 579 immune genes of T cells, UBE2L3, IL-6, STAT4, TYK2, TNFAIP3, and PTPN2 were significantly dysregulated in the relapse and remission of JIA cases [113]. Upregulation of HLA class II and another less-appreciated marker of T-cell activation, CD86, was found in the transcriptome profiling of $92 \%$ of JIA samples tested for DNA methylation [114]. Super-enhancers related to autoimmune diseases exist in T cells. Pro-inflammatory signals may inhibit the expression of disease-related genes by inhibiting the activity of super-enhancers [115]. Compared with that in sJIA patients, the number of HLA-DR + T cells and T cells coexpressing CD57 and CD16/56 increased in oligoarthritis JIA and polyarthritis JIA patients [116]. In general, transcriptome analysis of T cells is important for understanding the pathogenesis of JIA as well as its symptomatic treatment.

\section{Epigenomics Study of JIA}

It is well known that only about $2 \%$ of sequence in the human genome encodes proteins [117]. What roles do the remaining $98 \%$ noncoding regions play? Studies by genome annotations provided evidence that noncoding sequences can actually be transcribed into functional RNA molecules or bind transcription factors to fine-tune gene transcription in the both physiological and pathological processes $[118,119]$. In the era of GWAS, investigators discovered that the vast majority of SNPs associated with diseases were mapped to noncoding regions of the human genome, including intronic regions and intergenic regions [120].

Jiang et al. studied whether activation histone marks, i.e., enhancers H3K4me1 and H3K27ac, were enriched in the linkage disequilibrium (LD) blocks, containing 22 SNPs reported in the previous GWAS studies on JIA [121]. Chromatin immunoprecipitation (ChIP) followed by sequencing was 
used in human neutrophils and CD4+ T cells. The study showed that H3K4me1 and/or H3K27ac were enriched in 15 of 22 known JIA-associated loci. In addition, human CD4+ T cells had 18 regions with H3K4me1 and/or H3K27ac histone marks. The study also investigated noncoding RNAs (ncRNAs) within $5 \mathrm{~kb}$ of JIA-associated SNPs in human neutrophils, and found ncRNA transcripts in the rs4705862 and rs6894249 loci as determined by chromatin interaction analysis by paired-end tag sequencing (ChIA-PET) [121]. Consequently, the same research group showed that the JIA-associated LD blocks were enriched with H3K27ac and/or H3K4me1 marks, and these blocks bound with transcription factors in neutrophils [122]. In addition, the genes with critical immune functions, including HLA-DQA1, HLA-DQB2, TRAF1, and IRF1 have long-distance interactions within the LD blocks in human CD4+ T cells as determined by ChIA-PET [122].

The genome-wide analysis by Ellis et al. identified differential DNA methylation of promoter regions in peripheral blood CD4+ T cells from methotrexate-naïve JIA patients, compared to healthy controls, and found that reduced methylation at IL32 was associated with JIA [123]. Ai et al. collected fibroblast-like synoviocytes (FLS) from four early RA and three JIA patients, and used the previously reported 11 longstanding RA and 11 osteoarthritis as controls, to study DNA methylome signature. The study showed that early RA and JIA clustered with longstanding RA, but were different from osteoarthritis. JIA segregated with the longstanding RA group, and formed a subset in the RA super-group. These findings suggested that the inflammatory injuries in JIA and RA could be caused by abnormal methylation, and levels of methylation are related to the types and stages of disease [124].

Histone deacetylases (HDACs) are acetylation 'erasers' that can deacetylate both histone and non-histone proteins. HDACs are involved in cellular signaling, epigenetic regulation, and important in regulating the function of Teff cells and Treg cells [125]. Besides the above mentioned HLA class II molecules related sJIA that may be suitable to use abatacept, studies showed the epigenetic effects of HDAC9 in regulating critical innate immune processes through deacetylation of histone proteins [126,127]. HDAC inhibitors (HDACi) have been extensively studied for the application to the treatment of autoimmune diseases, such as Givinostat, a pan-class I/II HDACi, which is currently being investigated in JIA $[128,129]$, raising the possibility that HDACi represents plausible targeted therapeutic strategies in JIA.

\section{Conclusions}

JIA is a group of diseases, highly heterogeneous in terms of etiology and clinical presentation. Multiomics studies make significant contribution to the understanding of the genetic basis and molecular mechanism of JIA pathogenesis. Similar to other complex human diseases, only a small proportion of JIA familial cases can be attributable to single-gene mutations. For the majority of sporadic JIA cases, the development of the disease is shaped by genetic, epigenetic elements, and environmental factors. Though JIA was classified into seven subtypes, phenotypic overlap was observed between subtypes, suggesting shared genetic/epigenetic basis. The relative low prevalence of JIA makes it hard to acquire enough samples to carry out GWAS on each individual subtype. Proper statistical methods for meta-analysis are needed to identify genetic loci shared by JIA subtypes by taking into account of pleotropic effects and potentially different effect directions between subtypes, as well as small sample sizes. In addition to genetic components, epigenetic modifications also contribute to JIA pathogenesis and development. The shared and distinct epigenetic regulations between JIA subtypes are even less understood, and the interactions between genetic and epigenetic mechanisms warrant further investigation. Integrative analyses of genetic, epigenetic, and transcriptome data are needed to elucidate the full picture of underlying molecular mechanisms of JIA subtypes and to classify JIA cases by molecular markers, and to further facilitate drug development and drug repositioning. New molecular knowledge on different JIA subtypes encourages us to reconsider the JIA classification, but also highlights novel therapeutic targets to develop a cure for the devastating JIA.

Funding: This study was supported by National Natural Science Foundation of China (No.81771769), Tianjin Natural Science Foundation (No.18JCYBJC42700), Startup Funding from Tianjin Medical University. 
Conflicts of Interest: The authors declare no conflict of interest.

\section{References}

1. Thierry, S.; Fautrel, B.; Lemelle, I.; Guillemin, F. Prevalence and incidence of juvenile idiopathic arthritis: A systematic review. Jt. Bone Spine 2014, 81, 112-117. [CrossRef] [PubMed]

2. Fink, C.W. Proposal for the development of classification criteria for idiopathic arthritides of childhood. J. Rheumatol. 1995, 22, 1566-1569. [PubMed]

3. Thatayatikom, A.; De Leucio, A. Juvenile Idiopathic Arthritis (JIA); StatPearls, National Library of Medicine (NLM): Bethesda, MD, USA, 2020.

4. Martini, A. It is time to rethink juvenile idiopathic arthritis classification and nomenclature. Ann. Rheum. Dis. 2012, 71, 1437-1439. [CrossRef] [PubMed]

5. Martini, A.; Ravelli, A.; Avcin, T.; Beresford, M.W.; Burgos-Vargas, R.; Cuttica, R.; Ilowite, N.T.; Khubchandani, R.; Laxer, R.M.; Lovell, D.J. Toward New Classification Criteria for Juvenile Idiopathic Arthritis: First Steps, Pediatric Rheumatology International Trials Organization International Consensus. J. Rheumatol. 2018, 46, 190-197. [CrossRef]

6. Petty, R.E.; Southwood, T.R.; Manners, P.; Baum, J.; Glass, D.N.; Goldenberg, J.; He, X.; Maldonado-Cocco, J.; Orozco-Alcala, J.; Prieur, A.-M.; et al. International League of Associations for Rheumatology classification of juvenile idiopathic arthritis: Second revision, Edmonton, 2001. J. Rheumatol. 2004, 31, 390-392.

7. Guo, R.; Cao, L.; Kong, X.; Liu, X.; Xue, H.; Shen, L.; Li, X. Fever as an Initial Manifestation of Enthesitis-Related Arthritis Subtype of Juvenile Idiopathic Arthritis: Retrospective Study. PLoS ONE 2015, 10, e0128979. [CrossRef]

8. Masters, S.L.; Simon, A.; Aksentijevich, I.; Kastner, D.L. Horror Autoinflammaticus: The Molecular Pathophysiology of Autoinflammatory Disease. Annu. Rev. Immunol. 2009, 27, 621-668. [CrossRef]

9. De Jesus, A.A.; Goldbach-Mansky, R. Monogenic autoinflammatory diseases: Concept and clinical manifestations. Clin. Immunol. 2013, 147, 155-174. [CrossRef]

10. Hersh, A.O.; Prahalad, S. Immunogenetics of juvenile idiopathic arthritis: A comprehensive review. J. Autoimmun. 2015, 64, 113-124. [CrossRef]

11. Cader, M.Z.; Boroviak, K.; Zhang, Q.; Assadi, G.; Kempster, S.L.; Sewell, G.W.; Saveljeva, S.; Ashcroft, J.W.; Clare, S.; Mukhopadhyay, S.; et al. C13orf31 (FAMIN) is a central regulator of immunometabolic function. Nat. Immunol. 2016, 17, 1046-1056. [CrossRef]

12. Kallinich, T.; Thorwarth, A.; Von Stuckrad, S.-L.; Rösen-Wolff, A.; Luksch, H.; Hundsdoerfer, P.; Minden, K.; Krawitz, P.M. Juvenile arthritis caused by a novel FAMIN (LACC1) mutation in two children with systemic and extended oligoarticular course. Pediatr. Rheumatol. Online J. 2016, 14, 1-4. [CrossRef] [PubMed]

13. Rabionet, R.; Remesal, A.; Mensa-Vilaró, A.; Murías, S.; Alcobendas, R.; González-Roca, E.; Ruiz-Ortiz, E.; Antón, J.; Iglesias, E.; Modesto, C. Biallelic loss-of-function LACC1/FAMIN mutations presenting as rheumatoid factor-negative polyarticular juvenile idiopathic arthritis. Sci. Rep. 2019, 9, 1-6. [CrossRef] [PubMed]

14. Karacan, I.; Uğurlu, S.; Şahin, S.; Everest, E.; Kasapçopur, Ö.; Tolun, A.; Özdoğan, H.; Turanll, E.T.; Tolun, A. LACC1 Gene Defects in Familial Form of Juvenile Arthritis. J. Rheumatol. 2018, 45, 726-728. [CrossRef] [PubMed]

15. Wakil, S.M.; Monies, D.M.; Abouelhoda, M.; Altassan, N.A.; Al-Dusery, H.; Naim, E.A.; Al-Younes, B.; Shinwari, J.; Al-Mohanna, F.A.; Meyer, B.F.; et al. Association of a Mutation inLACC1With a Monogenic Form of Systemic Juvenile Idiopathic Arthritis. Arthritis Rheumatol. 2015, 67, 288-295. [CrossRef] [PubMed]

16. Lahiri, A.; Hedl, M.; Yan, J.; Abraham, C. Human LACC1 increases innate receptor-induced responses and a LACC1 disease-risk variant modulates these outcomes. Nat. Commun. 2017, 8, 15614. [CrossRef] [PubMed]

17. Szymanski, A.M.; Ombrello, M. Using genes to triangulate the pathophysiology of granulomatous autoinflammatory disease: NOD2, PLCG2 and LACC1. Int. Immunol. 2018, 30, 205-213. [CrossRef]

18. Skon-Hegg, C.; Zhang, J.; Wu, X.; Sagolla, M.; Ota, N.; Wuster, A.; Tom, J.; Doran, E.; Ramamoorthi, N.; Caplazi, P.; et al. LACC1 Regulates TNF and IL-17 in Mouse Models of Arthritis and Inflammation. J. Immunol. 2019, 202, 183-193. [CrossRef] 
19. Franke, A.; McGovern, D.P.B.; Barrett, J.C.; Wang, K.; Radford-Smith, G.L.; Ahmad, T.; Lees, C.W.; Balschun, T.; Lee, J.; Roberts, R.; et al. Genome-wide meta-analysis increases to 71 the number of confirmed Crohn's disease susceptibility loci. Nat. Genet. 2010, 42, 1118. [CrossRef]

20. Liu, H.; Irwanto, A.; Fu, X.; Yu, G.; Yu, Y.; Sun, Y.; Wang, C.; Wang, Z.; Okada, Y.; Low, H.; et al. Discovery of six new susceptibility loci and analysis of pleiotropic effects in leprosy. Nat. Genet. 2015, 47, 267. [CrossRef]

21. Takeuchi, M.; Mizuki, N.; Meguro, A.; Ombrello, M.J.; Kirino, Y.; Satorius, C.; Le, J.; Blake, M.; Erer, B.; Kawagoe, T. Dense genotyping of immune-related loci implicates host responses to microbial exposure in Behçet's disease susceptibility. Nature Genet. 2017, 49, 438. [CrossRef]

22. Wang, J.-W.; Howson, J.; Haller, E.; Kerr, W.G. Identification of a Novel Lipopolysaccharide-Inducible Gene with Key Features of Both a Kinase Anchor Proteins and chs1/beige Proteins. J. Immunol. 2001, 166, 4586-4595. [CrossRef] [PubMed]

23. Lo, B.; Fritz, J.M.; Su, H.C.; Uzel, G.; Jordan, M.B.; Lenardo, M.J. CHAI and LATAIE: New genetic diseases of CTLA-4 checkpoint insufficiency. Blood J. Am. Soc. Hematol. 2016, 128, 1037-1042. [CrossRef] [PubMed]

24. Alegre, M.-L.; Frauwirth, K.A.; Thompson, C.B. T-cell regulation by CD28 and CTLA-4. Nat. Rev. Immunol. 2001, 1, 220-228. [CrossRef] [PubMed]

25. Van Der Merwe, P.A.; Bodian, D.L.; Daenke, S.; Linsley, P.; Davis, S.J. CD80 (B7-1) Binds Both CD28 and CTLA-4 with a Low Affinity and Very Fast Kinetics. J. Exp. Med. 1997, 185, 393-404. [CrossRef]

26. Ostrov, D.A.; Shi, W.; Schwartz, J.C.; Almo, S.C.; Nathenson, S.G. Structure of Murine CTLA-4 and Its Role in Modulating T Cell Responsiveness. Science 2000, 290, 816-819. [CrossRef]

27. Cribbs, A.P.; Kennedy, A.; Penn, H.; Read, J.E.; Amjadi, P.; Green, P.; Syed, K.; Manka, S.W.; Brennan, F.M.; Gregory, B.; et al. Treg Cell Function in Rheumatoid Arthritis Is Compromised by CTLA-4 Promoter Methylation Resulting in a Failure to Activate the Indoleamine 2,3-Dioxygenase Pathway. Arthritis Rheumatol. 2014, 66, 2344-2354. [CrossRef]

28. Zhang, L.; Liang, H.; Guan, H.; Liu, H. Study of the association between CD28/CTLA-4 expression and disease activity in juvenile idiopathic arthritis. Exp. Ther. Med. 2015, 9, 1733-1738. [CrossRef]

29. Azizi, G.; Kiaee, F.; Hedayat, E.; Yazdani, R.; Dolatshahi, E.; Alinia, T.; Sharifi, L.; Mohammadi, H.; Kavosi, H.; Jadidi-Niaragh, F.; et al. Rheumatologic complications in a cohort of 227 patients with common variable immunodeficiency. Scand. J. Immunol. 2018, 87, e12663. [CrossRef]

30. Lopez-Herrera, G.; Tampella, G.; Pan-Hammarström, Q.; Herholz, P.; Trujillo-Vargas, C.M.; Phadwal, K.; Simon, A.K.; Moutschen, M.; Etzioni, A.; Mory, A.; et al. Deleterious Mutations in LRBA Are Associated with a Syndrome of Immune Deficiency and Autoimmunity. Am. J. Hum. Genet. 2012, 90, 986-1001. [CrossRef]

31. Oz, R.S.; Tesher, M.S. Arthritis in children with LRBA deficiency-Case report and literature review. Pediatr. Rheumatol. Online J. 2019, 17, 1-6. [CrossRef]

32. Gámez-Díaz, L.; Neumann, J.; Jäger, F.; Proietti, M.; Felber, F.; Soulas-Sprauel, P.; Perruzza, L.; Grassi, F.; Kögl, T.; Aichele, P.; et al. Immunological phenotype of the murine Lrba knockout. Immunol. Cell Biol. 2017, 95, 789-802. [CrossRef] [PubMed]

33. Kashiwada, M.; Cassel, S.L.; Colgan, J.D.; Rothman, P.B. NFIL3/E4BP4 controls type 2 T helper cell cytokine expression. EMBO J. 2011, 30, 2071-2082. [CrossRef] [PubMed]

34. Kobayashi, T.; Matsuoka, K.; Sheikh, S.Z.; Elloumi, H.Z.; Kamada, N.; Hisamatsu, T.; Hansen, J.J.; Doty, K.R.; Pope, S.D.; Smale, S.T.; et al. NFIL3 Is a Regulator of IL-12 p40 in Macrophages and Mucosal Immunity. J. Immunol. 2011, 186, 4649-4655. [CrossRef] [PubMed]

35. Schlenner, S.; Pasciuto, E.; Lagou, V.; Burton, O.; Prezzemolo, T.; Junius, S.; Roca, C.P.; Seillet, C.; Louis, C.; Dooley, J.; et al. NFIL3 mutations alter immune homeostasis and sensitise for arthritis pathology. Ann. Rheum. Dis. 2018, 78, 342-349. [CrossRef] [PubMed]

36. Feldmann, J.; Callebaut, I.; Raposo, G.; Certain, S.; Bacq, D.; Dumont, C.; Lambert, N.; Ouachée-Chardin, M.; Chedeville, G.; Tamary, H.; et al. Munc13-4 Is Essential for Cytolytic Granules Fusion and Is Mutated in a Form of Familial Hemophagocytic Lymphohistiocytosis (FHL3). Cell 2003, 115, 461-473. [CrossRef]

37. Schulert, G.S.; Zhang, M.; Husami, A.; Fall, N.; Brunner, H.; Zhang, K.; Cron, R.Q.; Grom, A.A. Brief Report: Novel UNC13D Intronic Variant Disrupting an NF-kB Enhancer in a Patient With Recurrent Macrophage Activation Syndrome and Systemic Juvenile Idiopathic Arthritis. Arthritis Rheumatol. 2018, 70, 963-970. [CrossRef] [PubMed] 
38. Zhang, K.; Biroschak, J.; Glass, D.N.; Thompson, S.D.; Finkel, T.; Passo, M.H.; Binstadt, B.A.; Filipovich, A.; Grom, A.A. Macrophage activation syndrome in patients with systemic juvenile idiopathic arthritis is associated with MUNC13-4 polymorphisms. Arthritis Rheum. 2008, 58, 2892-2896. [CrossRef]

39. Hazen, M.M.; Woodward, A.L.; Hofmann, I.; Degar, B.A.; Grom, A.; Filipovich, A.H.; Binstadt, B.A. Mutations of the hemophagocytic lymphohistiocytosis-associated geneUNC13D in a patient with systemic juvenile idiopathic arthritis. Arthritis Rheum. 2008, 58, 567-570. [CrossRef]

40. Moncrieffe, H.; Prahalad, S.; Thompson, S.D. Genetics of juvenile idiopathic arthritis: New tools bring new approaches. Curr. Opin. Rheumatol. 2014, 26, 579-584. [CrossRef]

41. Savolainen, A.; Saila, H.; Kotaniemi, K.; Kaipiainen-Seppan, O.; Leirisalo-Repo, M.; Aho, K. Magnitude of the genetic component in juvenile idiopathic arthritis. Ann. Rheum. Dis. 2000, 59, 1001. [CrossRef]

42. Hinks, A.; Registry, B.C.J.; Cobb, J.; Marion, M.C.; Prahalad, S.; Sudman, M.; Bowes, J.; Martin, P.; Comeau, M.E.; Sajuthi, S.; et al. Dense genotyping of immune-related disease regions identifies 14 new susceptibility loci for juvenile idiopathic arthritis. Nat. Genet. 2013, 45, 664-669. [CrossRef] [PubMed]

43. Førre, Ä.; Smerdel, A. Genetic epidemiology of juvenile idiopathic arthritis. Scand. J. Rheumatol. 2002, 31, 123-128. [CrossRef] [PubMed]

44. Solberg, O.D.; Mack, S.J.; Lancaster, A.K.; Single, R.M.; Tsai, Y.; Sanchez-Mazas, A.; Thomson, G. Balancing selection and heterogeneity across the classical human leukocyte antigen loci: A meta-analytic review of 497 population studies. Hum. Immunol. 2008, 69, 443-464. [CrossRef] [PubMed]

45. Arnaiz-Villena, A.; Gomez-Reino, J.J.; Gamir, M.L.; Regueiro, J.R.; Vicario, J.L.; Góamez-Reino, F.J.; Alonso, A.; Fernandez-Dapica, M.P.; Irigoyen, M.V.; Mateo, I.; et al. Dr, C4, and BF allotypes in juvenile rheumatoid arthritis. Arthritis Rheum. 1984, 27, 1281-1285. [CrossRef] [PubMed]

46. Hall, P.J.; Burman, S.J.; Laurent, M.R.; Briggs, D.; Venning, H.E.; Leak, A.M.; Bedford, P.A.; Ansell, B.M. Genetic susceptibility to early onset pauciarticular juvenile chronic arthritis: A study of HLA and complement markers in 158 British patients. Ann. Rheum. Dis. 1986, 45, 464-474. [CrossRef]

47. Vicario, J.L.; Martinez-Laso, J.; Gomez-Reino, J.J.; Gomez-Reino, F.J.; Regueiro, J.R.; Corell, A.; Segurado, O.G.; Arnaiz-Villena, A. Both HLA class II and class III DNA polymorphisms are linked to juvenile rheumatoid arthritis susceptibility. Clin. Immunol. Immunopathol. 1990, 56, 22-28. [CrossRef]

48. De Silvestri, A.; Capittini, C.; Poddighe, D.; Marseglia, G.L.; Mascaretti, L.; Bevilacqua, E.; Scotti, V.; Rebuffi, C.; Pasi, A.; Martinetti, M.; et al. HLA-DRB1 alleles and juvenile idiopathic arthritis: Diagnostic clues emerging from a meta-analysis. Autoimmun. Rev. 2017, 16, 1230-1236. [CrossRef]

49. Hollenbach, J.A.; Thompson, S.D.; Bugawan, T.L.; Ryan, M.; Sudman, M.; Marion, M.; Langefeld, C.D.; Thomson, G.; Erlich, H.A.; Glass, D.N. Juvenile idiopathic arthritis and HLA Class I and Class II interactions and age-at-onset effects. Arthritis Rheum. 2010, 62, 1781-1791. [CrossRef]

50. Paul, C.; Schoenwald, U.; Truckenbrodt, H.; Bettinotti, M.; Brünnler, G.; Keller, E.; Nevinny-Stickel, C.; Yao, Z.; Albert, E.D. HLA-DP/DR interaction in early onset pauciarticular juvenile chronic arthritis. Immunogenetics 1993, 37, 442-448. [CrossRef]

51. Hinks, A.; Bowes, J.; Cobb, J.; Ainsworth, H.C.; Marion, M.C.; Comeau, M.E.; Sudman, M.; Han, B.; Becker, M.L.; Bohnsack, J.F.; et al. Fine-mapping the MHC locus in juvenile idiopathic arthritis (JIA) reveals genetic heterogeneity corresponding to distinct adult inflammatory arthritic diseases. Ann. Rheum. Dis. 2016, 76, 765-772. [CrossRef]

52. Vehe, R.K.; Begovich, A.B.; Nepom, B.S. HLA susceptibility genes in rheumatoid factor positive juvenile rheumatoid arthritis. J. Rheumatol. Suppl. 1990, 26, 11-15. [PubMed]

53. Barron, K.S.; Silverman, E.D.; Gonzales, J.C.; Owerbach, D.; Reveille, J.D. DNA analysis of HLA-DR, DQ, and DP alleles in children with polyarticular juvenile rheumatoid arthritis. J. Rheumatol. 1992, $1,1611-1616$.

54. Thomson, W.; Barrett, J.H.; Donn, R.; Pepper, L.; Kennedy, L.J.; Ollier, W.E.R.; Silman, A.J.S.; Woo, P.; Southwood, T. Juvenile idiopathic arthritis classified by the ILAR criteria: HLA associations in UK patients. Rheumatology 2002, 41, 1183-1189. [CrossRef] [PubMed]

55. Prahalad, S.; Thompson, S.D.; Conneely, K.N.; Jiang, Y.; Leong, T.; Prozonic, J.; Brown, M.R.; Ponder, L.A.; Angeles-Han, S.T.; Vogler, L.B.; et al. Hierarchy of risk of childhood-onset rheumatoid arthritis conferred by HLA-DRB1 alleles encoding the shared epitope. Arthritis Rheum. 2012, 64, 925-930. [CrossRef] [PubMed] 
56. Hisa, K.; Yanagimachi, M.; Naruto, T.; Miyamae, T.; Kikuchi, M.; Hara, R.; Imagawa, T.; Yokota, S.; Mori, M. PADI4 and the HLA-DRB1 shared epitope in juvenile idiopathic arthritis. PLoS ONE 2017, 12, e0171961. [CrossRef] [PubMed]

57. Hinks, A.; Marion, M.C.; Cobb, J.; Comeau, M.E.; Sudman, M.; Ainsworth, H.C.; Bowes, J.; Becker, M.L.; Bohnsack, J.F.; Haas, J.-P.; et al. Brief Report: The Genetic Profile of Rheumatoid Factor-Positive Polyarticular Juvenile Idiopathic Arthritis Resembles That of Adult Rheumatoid Arthritis. Arthritis Rheumatol. 2018, 70, 957-962. [CrossRef] [PubMed]

58. De Bakker, P.I.; McVean, G.; Sabeti, P.C.; Miretti, M.M.; Green, T.; Marchini, J.; Ke, X.; Monsuur, A.J.; Whittaker, P.; Delgado, M.; et al. A high-resolution HLA and SNP haplotype map for disease association studies in the extended human MHC. Nat. Genet. 2006, 38, 1166-1172. [CrossRef]

59. Mahmud, S.A.; Binstadt, B.A. Autoantibodies in the Pathogenesis, Diagnosis, and Prognosis of Juvenile Idiopathic Arthritis. Front. Immunol. 2019, 9, 3168. [CrossRef]

60. Ombrello, M.; Remmers, E.F.; Tachmazidou, I.; Grom, A.; Foell, D.; Haas, J.-P.; Martini, A.; Gattorno, M.; Özen, S.; Prahalad, S.; et al. HLA-DRB1*11 and variants of the MHC class II locus are strong risk factors for systemic juvenile idiopathic arthritis. Proc. Natl. Acad. Sci. USA 2015, 112, 15970-15975. [CrossRef]

61. Stanevicha, V.; Eglite, J.; Zavadska, D.; Sochnevs, A.; Lazareva, A.; Guseinova, D.; Šantere, R.; Gardovska, D. HLA B27 allele types in homogeneous groups of juvenile idiopathic arthritis patients in Latvia. Pediatr. Rheumatol. Online J. 2010, 8, 26. [CrossRef]

62. Srivastava, R.; Phatak, S.; Yadav, A.; Bajpai, P.; Aggarwal, A. HLA B27 typing in 511 children with juvenile idiopathic arthritis from India. Rheumatol. Int. 2016, 36, 1407-1411. [CrossRef] [PubMed]

63. Kavadichanda, C.; Seth, G.; Kumar, G.; Gulati, R.; Negi, V.S. Clinical correlates of HLA-B*27 and its subtypes in enthesitis-related arthritis variant of juvenile idiopathic arthritis in south Indian Tamil patients. Int. J. Rheum. Dis. 2019, 22, 1289-1296. [CrossRef]

64. Shih, Y.-J.; Yang, Y.-H.; Lin, C.-Y.; Chang, C.-L.; Chiang, B.-L. Enthesitis-related arthritis is the most common category of juvenile idiopathic arthritis in Taiwan and presents persistent active disease. Pediatr. Rheumatol. Online J. 2019, 17, 1-8. [CrossRef] [PubMed]

65. Srivastava, R.; Agnihotry, S.; Aggarwal, R.; Bajpai, P.; Aggarwal, A. HLA-B27 subtypes in enthesitis-related arthritis category of juvenile idiopathic arthritis and ankylosing spondylitis in northern India. Clin. Exp. Rheumatol. 2015, 33, 931-935. [PubMed]

66. Eyre, S.; Bowes, J.; Diogo, D.; Lee, A.; Barton, A.; Martin, P.; Zhernakova, A.; Stahl, E.; Viatte, S.; McAllister, K.; et al. High-density genetic mapping identifies new susceptibility loci for rheumatoid arthritis. Nat. Genet. 2012, 44, 1336-1340. [CrossRef] [PubMed]

67. Hinks, A.; Barton, A.; Shephard, N.; Eyre, S.; Bowes, J.; Cargill, M.; Wang, E.; Ke, X.; Kennedy, G.C.; John, S.; et al. Identification of a novel susceptibility locus for juvenile idiopathic arthritis by genome-wide association analysis. Arthritis Rheum. 2009, 60, 258-263. [CrossRef] [PubMed]

68. Finkel, T.H.; Li, J.; Wei, Z.; Wang, W.; Zhang, H.; Behrens, E.M.; Reuschel, E.L.; Limou, S.; Wise, C.; Punaro, M.; et al. Variants in CXCR4 associate with juvenile idiopathic arthritis susceptibility. BMC Med. Genet. 2016, 17, 24. [CrossRef]

69. Hinks, A.; Barton, A.; John, S.; Bruce, I.; Hawkins, C.; Griffiths, C.E.M.; Donn, R.; Thomson, W.; Silman, A.; Worthington, J. Association between thePTPN22 gene and rheumatoid arthritis and juvenile idiopathic arthritis in a UK population: Further support thatPTPN22 is an autoimmunity gene. Arthritis Rheum. 2005, 52, 1694-1699. [CrossRef]

70. Wiede, F.; Shields, B.J.; Chew, S.H.; Kyparissoudis, K.; Van Vliet, C.; Galic, S.; Tremblay, M.L.; Russell, S.M.; Godfrey, D.I.; Tiganis, T. T cell protein tyrosine phosphatase attenuates T cell signaling to maintain tolerance in mice. J. Clin. Investig. 2011, 121, 4758-4774. [CrossRef]

71. Chiang, G.G.; Sefton, B.M. Specific Dephosphorylation of the Lck Tyrosine Protein Kinase at Tyr-394 by the SHP-1 Protein-tyrosine Phosphatase. J. Biol. Chem. 2001, 276, 23173-23178. [CrossRef]

72. Brownlie, R.J.; A Miosge, L.; Vassilakos, D.; Svensson, L.M.; Cope, A.P.; Zamoyska, R. Lack of the Phosphatase PTPN22 Increases Adhesion of Murine Regulatory T Cells to Improve Their Immunosuppressive Function. Sci. Signal. 2012, 5, ra87. [CrossRef]

73. Hasegawa, K.; Martin, F.; Huang, G.; Tumas, D.; Diehl, L.; Chan, A.C. PEST Domain-Enriched Tyrosine Phosphatase (PEP) Regulation of Effector/Memory T Cells. Science 2004, 303, 685-689. [CrossRef] 
74. Salmond, R.J.; Brownlie, R.J.; Zamoyska, R. Multifunctional roles of the autoimmune disease-associated tyrosine phosphatase PTPN22 in regulating T cell homeostasis. Cell Cycle 2015, 14, 705-711. [CrossRef]

75. Cho, J.-H.; Kim, H.-O.; Ju, Y.-J.; Kye, Y.-C.; Lee, G.-W.; Lee, S.-W.; Yun, C.-H.; Bottini, N.; Webster, K.; Goodnow, C.C.; et al. CD45-mediated control of TCR tuning in naïve and memory CD8+ T cells. Nat. Commun. 2016, 7, 13373. [CrossRef]

76. Li, Y.R.; Li, J.; Zhao, S.D.; Bradfield, J.P.; Mentch, F.D.; Maggadottir, S.M.; Hou, C.; Abrams, D.J.; Chang, D.; Gao, F.; et al. Meta-analysis of shared genetic architecture across ten pediatric autoimmune diseases. Nat. Med. 2015, 21, 1018-1027. [CrossRef]

77. Thompson, S.D.; Sudman, M.; Ramos, P.S.; Marion, M.C.; Ryan, M.; Tsoras, M.; Weiler, T.; Wagner, M.; Keddache, M.; Haas, J.-P.; et al. The susceptibility loci juvenile idiopathic arthritis shares with other autoimmune diseases extend to PTPN2, COG6, and ANGPT1. Arthritis Rheum. 2010, 62, 3265-3276. [CrossRef]

78. Thompson, S.D.; Marion, M.C.; Sudman, M.; Ryan, M.; Tsoras, M.; Howard, T.D.; Barnes, M.G.; Ramos, P.S.; Thomson, W.; Hinks, A.; et al. Genome-wide association analysis of juvenile idiopathic arthritis identifies a new susceptibility locus at chromosomal region 3q13. Arthritis Rheum. 2012, 64, 2781-2791. [CrossRef]

79. Cortes, A.; A Brown, M. Promise and pitfalls of the Immunochip. Arthritis Res. Ther. 2011, 13, 101. [CrossRef]

80. Ba, L.A.M.; Ma, M.C.M.; Sudman, M.; Ma, M.E.C.; Becker, M.L.; Bohnsack, J.F.; Fingerlin, T.E.; Griffin, T.A.; Haas, J.P.; Lovell, D.J.; et al. Genome-Wide Association Meta-Analysis Reveals Novel Juvenile Idiopathic Arthritis Susceptibility Loci. Arthritis Rheumatol. 2017, 69, 2222-2232. [CrossRef]

81. Redmond, W.L.; Ruby, C.E.; Weinberg, A.D. The Role of OX40-Mediated Co-stimulation in T-Cell Activation and Survival. Crit. Rev. Immunol. 2009, 29, 187-201. [CrossRef]

82. Zervou, M.I.; Dimopoulou, D.G.; Eliopoulos, E.; Trachana, M.; Pratsidou-Gkertsi, P.; Andreou, A.; Sidiropoulos, P.; Spandidos, D.A.; Garyfallos, A.; Goulielmos, G.N. The genetics of juvenile idiopathic arthritis: Searching for new susceptibility loci. Mol. Med. Rep. 2017, 16, 8793-8798. [CrossRef]

83. Couturier, N.; Bucciarelli, F.; Nurtdinov, R.N.; Debouverie, M.; Lebrun, C.; Defer, G.; Moreau, T.; Confavreux, C.; Vukusic, S.; Cournu-Rebeix, I.; et al. Tyrosine kinase 2 variant influences T lymphocyte polarization and multiple sclerosis susceptibility. Brain 2011, 134, 693-703. [CrossRef]

84. Omar, A.; Abo-Elyoun, I.; Hussein, H.; Nabih, M.; Atwa, H.; Gad, S.; Emad, Y. Anti-cyclic citrullinated peptide (anti-CCP) antibody in juvenile idiopathic arthritis (JIA): Correlations with disease activity and severity of joint damage (a multicenter trial). Jt. Bone Spine 2013, 80, 38-43. [CrossRef]

85. Prahalad, S.; Conneely, K.N.; Jiang, Y.; Sudman, M.; Wallace, C.A.; Brown, M.R.; Ponder, L.A.; Rohani-Pichavant, M.; Zwick, M.E.; Cutler, D.J.; et al. Susceptibility to childhood-onset rheumatoid arthritis: Investigation of a weighted genetic risk score that integrates cumulative effects of variants at five genetic loci. Arthritis Rheum. 2013, 65, 1663-1667. [CrossRef] [PubMed]

86. Fishman, D.; Faulds, G.; Jeffery, R.; Mohamed-Ali, V.; Yudkin, J.S.; Humphries, S.; Woo, P. The effect of novel polymorphisms in the interleukin-6 (IL-6) gene on IL-6 transcription and plasma IL-6 levels, and an association with systemic-onset juvenile chronic arthritis. J. Clin. Investig. 1998, 102, 1369-1376. [CrossRef] [PubMed]

87. Ogilvie, E.M.; Fife, M.S.; Thompson, S.D.; Twine, N.; Tsoras, M.; Moroldo, M.; Fisher, S.A.; Lewis, C.M.; Prieur, A.-M.; Glass, D.N.; et al. The $-174 \mathrm{G}$ allele of the interleukin-6 gene confers susceptibility to systemic arthritis in children: A multicenter study using simplex and multiplex juvenile idiopathic arthritis families. Arthritis Rheum. 2003, 48, 3202-3206. [CrossRef] [PubMed]

88. Donn, R.P.; Shelley, E.; Ollier, W.E.R.; Thomson, W.; British Paediatric Rheumatology Study Group. A novel 5 -flanking region polymorphism of macrophage migration inhibitory factor is associated with systemic-onset juvenile idiopathic arthritis. Arthritis Rheum. 2001, 44, 1782-1785. [CrossRef]

89. De Benedetti, F.; Meazza, C.; Vivarelli, M.; Rossi, F.; Pistorio, A.; Lamb, R.; Lunt, M.; Thomson, W.; Ravelli, A.; Donn, R.; et al. Functional and prognostic relevance of the -173 polymorphism of the macrophage migration inhibitory factor gene in systemic-onset juvenile idiopathic arthritis. Arthritis Rheum. 2003, 48, 1398-1407. [CrossRef]

90. Fife, M.; Gutierrez, A.; Ogilvie, E.M.; Stock, C.J.; Samuel, J.M.; Thomson, W.; Mack, L.F.; Lewis, C.M.; Woo, P. Novel IL10 gene family associations with systemic juvenile idiopathic arthritis. Arthritis Res. Ther. 2006, 8, R148. [CrossRef] 
91. Omoyinmi, E.; Forabosco, P.; Hamaoui, R.; Bryant, A.; Hinks, A.; Ursu, S.; Wedderburn, L.R.; Thomson, W.; Lewis, C.M.; Woo, P. Association of the IL-10 Gene Family Locus on Chromosome 1 with Juvenile Idiopathic Arthritis (JIA). PLoS ONE 2012, 7, e47673. [CrossRef]

92. Stock, C.J.; Ogilvie, E.M.; Samuel, J.M.; Fife, M.; Lewis, C.M.; Woo, P. Comprehensive association study of genetic variants in the IL-1 gene family in systemic juvenile idiopathic arthritis. Genes Immun. 2008, 9, 349-357. [CrossRef] [PubMed]

93. Hinks, A.; Martin, P.; Thompson, S.D.; Sudman, M.; Stock, C.J.; Thomson, W.; Day, T.G.; Packham, J.; Ramanan, A.V.; Donn, R. Autoinflammatory gene polymorphisms and susceptibility to UK juvenile idiopathic arthritis. Pediatr. Rheumatol. Online J. 2013, 11, 14. [CrossRef] [PubMed]

94. Scheibel, I.; Veit, T.; Neves, A.G.; Souza, L.; Prezzi, S.; Machado, S.; Kohem, C.; Icarelli, M.; Xavier, R.M.; Brenol, J.C.; et al. Differential CCR5 $\Delta 32$ allelic frequencies in juvenile idiopathic arthritis subtypes: Evidence for different regulatory roles of CCR5 in rheumatological diseases. Scand. J. Rheumatol. 2008, 37, $13-17$. [CrossRef] [PubMed]

95. Lamb, R.; Thomson, W.; British Society of Paediatric and Adolescent Rheumatology; Ogilvie, E.M.; Donn, R. Positive association ofSLC26A2 gene polymorphisms with susceptibility to systemic-onset juvenile idiopathic arthritis. Arthritis Rheum. 2007, 56, 1286-1291. [CrossRef] [PubMed]

96. Bukulmez,H.; Fife, M.; Tsoras, M.; Thompson, S.D.; Twine, N.A.; Woo, P.; Olson, J.M.; Elston, R.C.; Glass, D.N.; Colbert, R.A. Tapasin gene polymorphism in systemic onset juvenile rheumatoid arthritis: A family-based case-control study. Arthritis Res. Ther. 2005, 7, R285-R290. [CrossRef] [PubMed]

97. Ombrello, M.; Arthur, V.L.; Remmers, E.F.; Hinks, A.; Tachmazidou, I.; A Grom, A.; Foell, D.; Martini, A.; Gattorno, M.; Özen, S.; et al. Genetic architecture distinguishes systemic juvenile idiopathic arthritis from other forms of juvenile idiopathic arthritis: Clinical and therapeutic implications. Ann. Rheum. Dis. 2016, 76, 906-913. [CrossRef]

98. Bharti, S.; Handrow-Metzmacher, H.; Zickenheiner, S.; Zeitvogel, A.; Baumann, R.; Starzinski-Powitz, A. Novel Membrane Protein shrew-1 Targets to Cadherin-Mediated Junctions in Polarized Epithelial Cells. Mol. Biol. Cell 2004, 15, 397-406. [CrossRef]

99. Ruperto, N.; Lovell, D.J.; Quartier, P.; Paz, E.; Rubio-Pérez, N.; Silva, C.A.; Abud-Mendoza, C.; Burgos-Vargas, R.; Gerloni, V.; Melo-Gomes, J.A.; et al. Abatacept in children with juvenile idiopathic arthritis: A randomised, double-blind, placebo-controlled withdrawal trial. Lancet 2008, 372, 383-391. [CrossRef]

100. Record, J.L.; Beukelman, T.; Cron, R.Q.; Hasegawa, M.; Segawa, T.; Maeda, M.; Yoshida, T.; Sudo, A. Combination Therapy of Abatacept and Anakinra in Children with Refractory Systemic Juvenile Idiopathic Arthritis: A Retrospective Case Series. J. Rheumatol. 2011, 38, 180-181. [CrossRef]

101. Arthur, V.L.; Shuldiner, E.; Remmers, E.F.; Hinks, A.; Grom, A.A.; Foell, D.; Martini, A.; Gattorno, M.; Ozen, S.; Prahalad, S.; et al. IL1RN Variation Influences Both Disease Susceptibility and Response to Recombinant Human Interleukin-1 Receptor Antagonist Therapy in Systemic Juvenile Idiopathic Arthritis. Arthritis Rheumatol. 2018, 70, 1319-1330. [CrossRef]

102. Mo, A.; Marigorta, U.M.; Gulick, D.; Chan, L.H.K.; Ponder, L.; Jang, S.R.; Prince, J.; Kugathasan, S.; Prahalad, S.; Gibson, G. Disease-specific regulation of gene expression in a comparative analysis of juvenile idiopathic arthritis and inflammatory bowel disease. Genome Med. 2018, 10, 48. [CrossRef] [PubMed]

103. Ogilvie, E.M.; Khan, A.; Hubank, M.; Kellam, P.; Woo, P. Specific gene expression profiles in systemic juvenile idiopathic arthritis. Arthritis Rheum. 2007, 56, 1954-1965. [CrossRef] [PubMed]

104. Griffin, T.A.; Barnes, M.G.; Ilowite, N.T.; Olson, J.C.; Sherry, D.D.; Gottlieb, B.S.; Aronow, B.J.; Pavlidis, P.; Hinze, C.H.; Thornton, S.; et al. Gene expression signatures in polyarticular juvenile idiopathic arthritis demonstrate disease heterogeneity and offer a molecular classification of disease subsets. Arthritis Rheum. 2009, 60, 2113-2123. [CrossRef] [PubMed]

105. Ter Haar, N.M.; Tak, T.; Mokry, M.; Scholman, R.C.; Meerding, J.M.; De Jager, W.; Verwoerd, A.; Foell, D.; Vogl, T.; Roth, J.; et al. Reversal of Sepsis-Like Features of Neutrophils by Interleukin-1 Blockade in Patients With Systemic-Onset Juvenile Idiopathic Arthritis. Arthritis Rheumatol. 2018, 70, 943-956. [CrossRef] [PubMed]

106. Brown, R.; Henderlight, M.; Do, T.; Yasin, S.; Grom, A.A.; DeLay, M.; Thornton, S.; Schulert, G.S. Neutrophils From Children With Systemic Juvenile Idiopathic Arthritis Exhibit Persistent Proinflammatory Activation Despite Long-Standing Clinically Inactive Disease. Front. Immunol. 2018, 9. [CrossRef] [PubMed] 
107. Bleesing, J.; Prada, A.; Siegel, D.M.; Villanueva, J.; Olson, J.; Ilowite, N.T.; Brunner, H.I.; Griffin, T.; Graham, T.B.; Sherry, D.D.; et al. The diagnostic significance of soluble CD163 and soluble interleukin-2 receptor $\alpha$-chain in macrophage activation syndrome and untreated new-onset systemic juvenile idiopathic arthritis. Arthritis Rheum. 2007, 56, 965-971. [CrossRef] [PubMed]

108. Schulert, G.S.; Fall, N.; Harley, J.B.; Shen, N.; Lovell, D.J.; Thornton, S.; Grom, A.A. Monocyte MicroRNA Expression in Active Systemic Juvenile Idiopathic Arthritis Implicates MicroRNA-125a-5p in Polarized Monocyte Phenotypes. Arthritis Rheumatol. 2016, 68, 2300-2313. [CrossRef]

109. Kamiya, Y.; Kawada, J.-I.; Kawano, Y.; Torii, Y.; Kawabe, S.; Iwata, N.; Ito, Y. Serum microRNAs as Potential Biomarkers of Juvenile Idiopathic Arthritis. Clin. Rheumatol. 2015, 34, 1705-1712. [CrossRef]

110. Do, T.; Tan, R.; Bennett, M.F.; Medvedovic, M.; Grom, A.A.; Shen, N.; Thornton, S.; Schulert, G.S. MicroRNA networks associated with active systemic juvenile idiopathic arthritis regulate CD163 expression and anti-inflammatory functions in macrophages through two distinct mechanisms. J. Leukoc. Biol. 2017, 103, 71-85. [CrossRef]

111. Moncrieffe, H.; Bennett, M.F.; Tsoras, M.; Luyrink, L.K.; Johnson, A.L.; Xu, H.; Dare, J.; Becker, M.L.; Prahalad, S.; Rosenkranz, M.; et al. Transcriptional profiles of JIA patient blood with subsequent poor response to methotrexate. Rheumatology 2017, 56, 1542-1551. [CrossRef]

112. Schulert, G.S.; Yasin, S.; Carey, B.; Chalk, C.; Do, T.; Schapiro, A.H.; Husami, A.; Watts, A.; Brunner, H.I.; Huggins, J.; et al. Systemic Juvenile Idiopathic Arthritis-Associated Lung Disease: Characterization and Risk Factors. Arthritis Rheumatol. 2019, 71, 1943-1954. [CrossRef]

113. Leong, J.Y.; Chen, P.; Yeo, J.G.; Ally, F.; Chua, C.; Hazirah, S.N.; Poh, S.L.; Pan, L.; Lai, L.; Lee, E.S.C.; et al. Immunome perturbation is present in patients with juvenile idiopathic arthritis who are in remission and will relapse upon anti-TNF $\alpha$ withdrawal. Ann. Rheum. Dis. 2019, 78, 1712-1721. [CrossRef] [PubMed]

114. Spreafico, R.; Rossetti, M.; Whitaker, J.W.; Wang, W.; Lovell, D.J.; Albani, S. Epipolymorphisms associated with the clinical outcome of autoimmune arthritis affect CD4+T cell activation pathways. Proc. Natl. Acad. Sci. USA 2016, 113, 13845-13850. [CrossRef] [PubMed]

115. Peeters, J.G.; Vervoort, S.J.; Tan, S.; Mijnheer, G.; De Roock, S.; Vastert, S.J.; Nieuwenhuis, E.E.S.; Van Wijk, F.; Prakken, B.J.; Creyghton, M.P.; et al. Inhibition of Super-Enhancer Activity in Autoinflammatory Site-Derived T Cells Reduces Disease-Associated Gene Expression. Cell Rep. 2015, 12, 1986-1996. [CrossRef] [PubMed]

116. Wouters, C.H.; Ceuppens, J.L.; Stevens, E.A.M. Different circulating lymphocyte profiles in patients with different subtypes of juvenile idiopathic arthritis. Clin. Exp. Rheumatol. 2002, 20, 239-248. [PubMed]

117. Stamatoyannopoulos, J. What does our genome encode? Genome Res. 2012, 22, 1602-1611. [CrossRef] [PubMed]

118. Jacquier, A. The complex eukaryotic transcriptome: Unexpected pervasive transcription and novel small RNAs. Nat. Rev. Genet. 2009, 10, 833-844. [CrossRef]

119. Kapranov, P.; Willingham, A.T.; Gingeras, T.R. Genome-wide transcription and the implications for genomic organization. Nat. Rev. Genet. 2007, 8, 413-423. [CrossRef]

120. Maurano, M.T.; Humbert, R.; Rynes, E.; Thurman, R.E.; Haugen, E.; Wang, H.; Reynolds, A.P.; Sandstrom, R.; Qu, H.; Brody, J.; et al. Systematic Localization of Common Disease-Associated Variation in Regulatory DNA. Science 2012, 337, 1190-1195. [CrossRef]

121. Jiang, K.; Zhu, L.; Buck, M.J.; Chen, Y.; Carrier, B.; Liu, T.; Jarvis, J.N. Disease-Associated Single-Nucleotide Polymorphisms From Noncoding Regions in Juvenile Idiopathic Arthritis Are Located Within or Adjacent to Functional Genomic Elements of Human Neutrophils and CD4+ T Cells. Arthritis Rheumatol. 2015, 67, 1966-1977. [CrossRef]

122. Zhu, L.; Jiang, K.; Webber, K.; Wong, L.P.; Liu, T.; Chen, Y.; Jarvis, J.N. Chromatin landscapes and genetic risk for juvenile idiopathic arthritis. Arthritis Res. Ther. 2017, 19, 57. [CrossRef] [PubMed]

123. Ellis, J.A.; Munro, J.E.; Chavez, R.A.; Gordon, L.; Joo, J.E.; Akikusa, J.D.; Allen, R.C.; Ponsonby, A.-L.; Craig, J.M.; Saffery, R. Genome-scale case-control analysis of CD4+ T-cell DNA methylation in juvenile idiopathic arthritis reveals potential targets involved in disease. Clin. Epigenetics 2012, 4, 20. [CrossRef] [PubMed]

124. Ai, R.; Whitaker, J.W.; Boyle, D.L.; Tak, P.P.; Gerlag, D.M.; Wang, W.; Firestein, G.S. DNA Methylome Signature in Synoviocytes from Patients with Early Rheumatoid Arthritis Compared to Synoviocytes from Patients with Longstanding Rheumatoid Arthritis. Arthritis Rheumatol. 2015, 67, 1978-1980. [CrossRef] [PubMed] 
125. Nijhuis, L.; Peeters, J.G.C.; Vastert, S.J.; Van Loosdregt, J. Restoring T Cell Tolerance, Exploring the Potential of Histone Deacetylase Inhibitors for the Treatment of Juvenile Idiopathic Arthritis. Front. Immunol. 2019, 10, 151. [CrossRef] [PubMed]

126. Birnbaum, R.Y.; Clowney, E.J.; Agamy, O.; Kim, M.J.; Zhao, J.; Yamanaka, T.; Pappalardo, Z.; Clarke, S.L.; Wenger, A.M.; Nguyen, L.; et al. Coding exons function as tissue-specific enhancers of nearby genes. Genome Res. 2012, 22, 1059-1068. [CrossRef]

127. Li, X.; Zhang, Q.; Ding, Y.; Liu, Y.; Zhao, D.; Zhao, K.; Shen, Q.; Liu, X.; Zhu, X.; Li, N.; et al. Methyltransferase Dnmt3a upregulates HDAC9 to deacetylate the kinase TBK1 for activation of antiviral innate immunity. Nat. Immunol. 2016, 17, 806-815. [CrossRef]

128. Vojinovic, J.; Damjanov, N. HDAC Inhibition in Rheumatoid Arthritis and Juvenile Idiopathic Arthritis. Mol. Med. 2011, 17, 397-403. [CrossRef]

129. Vojinovic, J.; Damjanov, N.; D’Urzo, C.; Furlan, A.; Susic, G.; Pasic, S.; Iagaru, N.; Stefan, M.; Dinarello, C.A. Safety and efficacy of an oral histone deacetylase inhibitor in systemic-onset juvenile idiopathic arthritis. Arthritis Rheum. 2011, 63, 1452-1458. [CrossRef]

Publisher's Note: MDPI stays neutral with regard to jurisdictional claims in published maps and institutional affiliations.

(C) 2020 by the authors. Licensee MDPI, Basel, Switzerland. This article is an open access article distributed under the terms and conditions of the Creative Commons Attribution (CC BY) license (http://creativecommons.org/licenses/by/4.0/). 